Article

\title{
Extending a Large-scale Model to Better Represent Water Re- sources without Increasing the Model Complexity
}

\author{
Robyn Horan ${ }^{1}$, Nathan J. Rickards ${ }^{1 *}$, Alexandra Kaelin ${ }^{1}$, Helen E. Baron ${ }^{1}$, Thomas Thomas ${ }^{2}$, Virginie D.J. Keller1, \\ Prabhas K. Mishra ${ }^{2}$, Manish K. Nema' ${ }^{2}$, Sekhar Muddu ${ }^{3}$, Kaushal K. Garg ${ }^{4}$, Rishi Pathak ${ }^{2}$, Helen A. Houghton- \\ Carr ${ }^{1}$, Harry Dixon ${ }^{1}$, Sharad K. Jain ${ }^{2}$ and Gwyn Rees ${ }^{1}$
}

1 UK Centre for Ecology \& Hydrology, Wallingford OX10 8BB, UK; robynhoran8@gmail.com (RH), natric@ceh.ac.uk (NJR), akaelin.mail@gmail.com (AK), heron@ceh.ac.uk (HEB), vke@ceh.ac.uk (VDJK), hahc@ceh.ac.uk (HAHC), harr@ceh.ac.uk (HD), hgrees@ceh.ac.uk (GR).

2 National Institute of Hydrology, Roorkee 247667, India; thomas_nih@yahoo.com (TT), erprabhash@gmail.com (PKM), mxnema@gmail.com (MKN), rishicswe@gmail.com (RP), s_k_jain@yahoo.com (SKJ).

3 Department of Civil Engineering, Indian Institute of Science, Bangalore 560012, India; sekhar.muddu@gmail.com (SM).

4 International Crops Research Institute for the Semi-Arid Tropics, Hyderabad 502324, India; K.GARG@cgiar.org (KKG).

* Correspondence: natric@ceh.ac.uk

\begin{abstract}
A robust hydrological assessment is challenging in regions where human interference, within all aspects of the hydrological system, significantly alters the flow regime of rivers. The challenge was to extend a large-scale water resources model, GWAVA, to better represent water resources without increasing the model complexity. A groundwater and a regulated reservoir routine were incorporated into GWAVA using modifications of the existing AMBHAS-1D and Hanasaki methodologies, respectively. The groundwater routine can be varied in complexity when sufficient input data is available but fundamentally is driven by three input parameters. The reservoir routine was extended to account for the presence of large, regulated reservoirs using two calibratable parameters. The additional groundwater processes and reservoir regulation was tested in two highly anthropogenically influenced basins in India: the Cauvery and Narmada. The inclusion of the revised groundwater routine improved the simulation of streamflow in the headwater catchments and was successful in improving the representation of the baseflow component. In addition, the model was able to produce a time series of daily groundwater levels, recharge to groundwater and groundwater abstraction. The regulated reservoir routine improved the simulation of streamflow in catchments downstream of major reservoirs, where the streamflow was largely reflective of reservoir releases, when calibrated using downstream observed streamflow records. The model was able to provide a more robust representation of the annual volume and daily outflow released from the major reservoirs and simulate the major reservoir storages adequately. The addition of one-dimensional groundwater processes and a regulated reservoir routine proved successful in improving the model performance and traceability of water balance components, without excessively increasing the model complexity and input data requirements.
\end{abstract}

Keywords: large-scale model; hydrology; groundwater; reservoirs; Cauvery; Narmada

\section{Introduction}

Humans are increasingly altering the hydrological cycle through the construction of reservoirs, changes in land use, water abstractions and urbanisation [1]. Accurate quantification of freshwater flows and storage is therefore important to support water management and governance in the near and far future [2]. Large-scale hydrological modelling 
estimates water fluxes, such as evapotranspiration, river discharge and groundwater recharge, and water storage, including soil water, groundwater and reservoirs $[1,3,4]$ at a basin or continental scale.

GWAVA is a large-scale gridded water resources model [5] which accounts for natural hydrological processes (soils, land use and lakes) using a conceptual rainfall-runoff model and anthropogenic stresses (groundwater abstraction, irrigation, domestic and industrial demands, reservoir storage and water transfers) using a demand-driven routine. The model can be run at a daily or monthly time scale and is adaptable to the data availability of the region. GWAVA was developed primarily for use in large, data-scarce regions. The model comprises only eleven mandatory parameters- four parameters pertaining to the physical parameters of the basin, three-time series pertaining to the climate variables (precipitation, potential evaporation, temperature) and four calibratable factors. The model further incorporates five reservoir parameters, nineteen water demand constraints and six characteristics of mountains and glaciers that are optional input when the relevant data is available. GWAVA, however, does not comprehensively account for groundwater processes or regulated reservoir releases.

GWAVA has a simplistic representation of groundwater. The groundwater store for each grid cell receives groundwater recharge from the soil moisture storage. As a basic representation of deeper groundwater processes, water can drain to the groundwater store, and water draining from the groundwater store is lost from the system. Water abstractions from the groundwater store are decoupled and are not abstracted in each time step but summed at the completion of the run. GWAVA simulates regulated reservoir release using a non-linear equation utilising mean inflow, reservoir capacity and two outflow parameters.

Groundwater accounts for approximately a third of total water withdrawals globally, and an estimated two billion people rely on groundwater as their primary source of water. Additionally, more than half of the irrigation water globally is abstracted from groundwater sources [6]. It is therefore important to select a model that can accurately simulate the generation of groundwater, particularly in basins where the main source of baseflow is dependent upon groundwater storage [7].

A better representation of groundwater processes needs to be included in large-scale hydrological models to improve simulations and the understanding of feedbacks between the human and natural systems [8 - 10]. Simple one-dimensional groundwater routines currently exist within HiGW-MAT (Human Intervention and Ground Water coupled MATSIRO) [9], H08 [11], PCR-GLOBWB [12], CWatM [13], WaterGAP [14] and VIC [15], with the focus on quantity and change in groundwater storage. Most models allow for groundwater to be recharged through rainfall, wetlands and reservoirs. Groundwater abstractions are often incorporated to meet demand As far as the author is aware, none of these models, except VIC [10], consider lateral flow within the groundwater store without being fully coupled to MOD-FLOW [16]. Using MOD-FLOW significantly increases the data and computational requirements.

Approximately one-sixth of the annual river discharge globally available is stored as a result of the construction of an estimated 70300 reservoirs [17]. Reservoir operations have a considerable impact on the natural discharge regime of a river. Simulating the available storage, volume and timing of reservoir releases pose a significant challenge to hydrological modelling at a basin and continental scale [18]. Reservoir operational data are rarely freely available, if at all. Therefore, hydrological models include various schemes to estimate reservoir storage and releases.

A module that optimises reservoir outflow based on the operating purpose of the reservoir is included in VIC [19], WaterGAP [20] and H08 using the Hanasaki reservoir routine [21, 22], and H08 has been updated to represent water transfers and local reservoirs [11]. The reservoir scheme used in LPJmL [23] combines aspects used in H08 [22] and VIC [19]. Monthly target releases are calculated for each month of each operational year according to the primary purpose of the reservoir. The reservoir scheme in PCRGLOBWB [12] is based on that included with VIC [19], but uses estimates of future inflows 
and demands via a weighted average of antecedent conditions. CWatM utilises a function of three storage limits and three outflow functions to determine reservoir releases. The storage limits are user-specified and depend on the physical characteristics of the reservoir. Other examples of recent reservoir routine implementations include, but are not limited to, SWAT [24], DHSVM [18], VIC [10], MESH [25] and HYPE [26].

\section{Model Applications}

\subsection{Catchment Descriptions}

The Narmada and the Cauvery basins (Error! Reference source not found.) are situated in Peninsula India and are the fifth and sixth largest river basins in India respectively. Both basins are snow-free, highly anthropogenically influenced and reservoir regulated to sustain the livelihoods of a collective 45 million people. The basins experience a large degree of heterogeneity, not only in topography and land use but also in climate and economic development [27]. Both basins are highly regulated by reservoir releases, with a visible impact on the downstream flows. The Narmada is sustained by base flow through the dry periods, and the domestic and agriculture activities in the Cauvery are highly dependent on groundwater sources. Both basins suffer water scarcity, therefore the modelling and understanding of water resources is important for water management. Thus, it is critically important that both reservoir releases and groundwater are accurately represented to undertake effective water resources modelling exercises.

The current hydrological functioning of the Cauvery Basin has been significantly altered over the last century by water supply infrastructure, urbanisation, land-use change and increased groundwater use. The Cauvery Basin is situated predominantly within the federal states of Karnataka and Tamil Nadu [28], and has been identified as highly waterstressed [29]. Despite rapidly developing urban and industrial centres, irrigation throughout the basin requires approximately $90 \%$ of the total water resources [30]. The basin is highly regulated by aggressive groundwater pumping and reservoir releases along the tributaries and main channel, with surface water flows only reaching the Bay of Bengal in years of strong monsoons [31]. Several hydrological modelling exercises have been carried out in the Cauvery Basin or sub-catchments thereof. Remote sensing methods [32], ANN model [32], GWAVA model [33, 34], VIC model [34] and the SWAT model [34, 35] have been applied in various sub-catchments of the Cauvery. At a basin scale, SWAT [36 - 39], SCS-CN [40, 41], and VIC-MHM [42] have been used to simulate various components of the hydrological cycle.

The Narmada Basin is facing numerous resource management challenges, including state and sectoral competition for water. This highly regulated river flows through the states of Chhattisgarh, Madhya Pradesh, Maharashtra and Gujarat, housing more than 250 dams of various sizes and purposes [43]. More than half of the basin is used for agriculture, with most of this land within designated irrigation command areas. The agriculture within the command areas is highly intensified, with an average cropping intensity of 135\% [44]. The low flows in the basin are sustained by base flow and reservoir releases. The Narmada has been modelled at the basin-scale using the SCS-CN method [45], VICMHM [42] and geoinformatics [46]. Sub-catchments of the Narmada have been represented using SHE [47], SCS-CN [48 - 50], and SWAT [51]. The above-mentioned studies focussing on the Cauvery and the Narmada Basins highlight the minimal representation of anthropogenic influences, groundwater abstraction and reservoir operations within existing modelling exercises. GWAVA has been applied in both the Cauvery basin [33, 34] and the Upper Narmada basin [52]. These publications highlight the need for a more comprehensive reservoir routine when modelling highly regulated basins, and for the inclusion of a coupled groundwater module to account for the limitations of natural groundwater resources and groundwater abstraction to meet anthropogenic demand. 


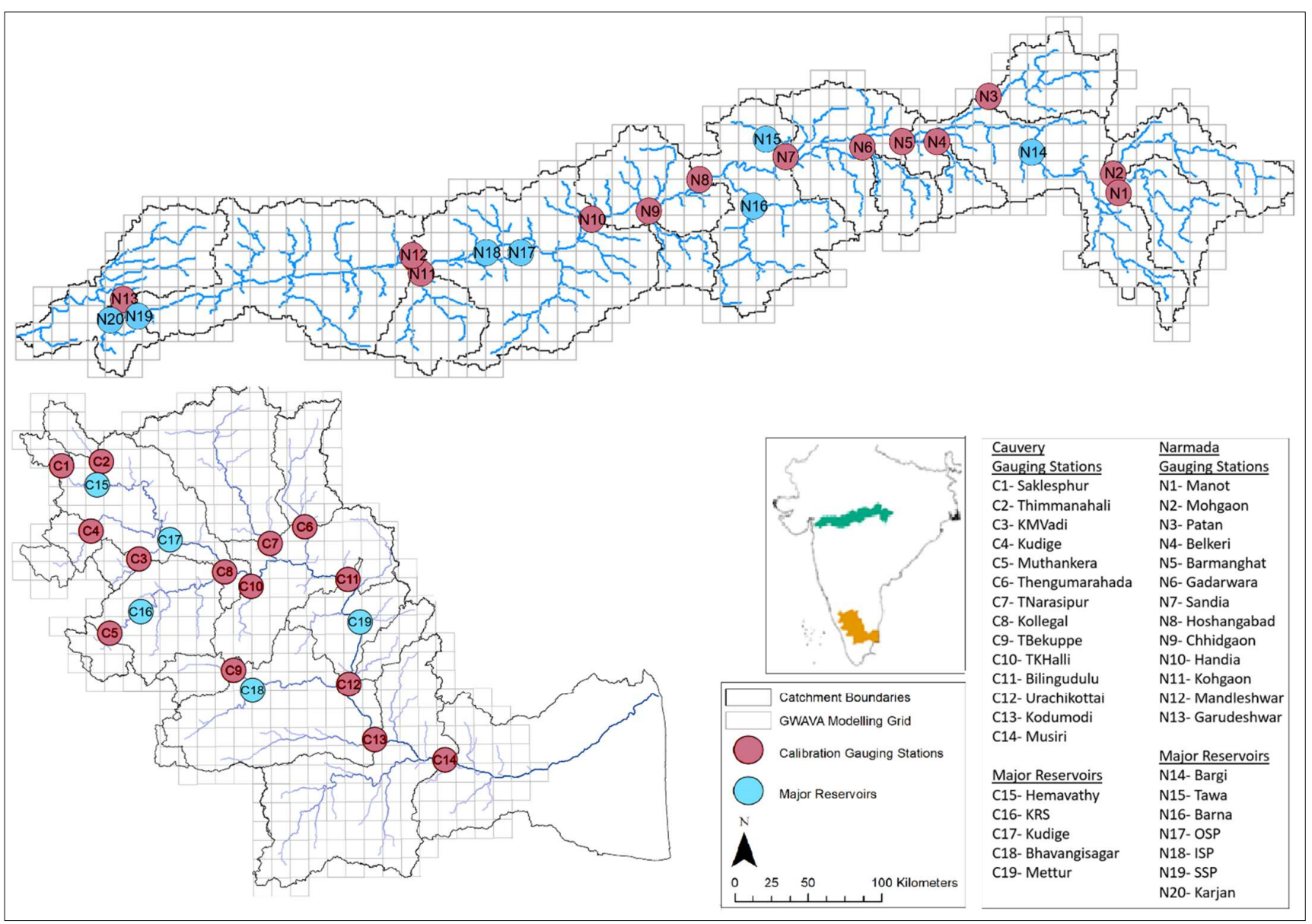

Figure 1. Inset: the location of the Cauvery and Narmada Basins within India; main maps: sub-catchment boundaries, modelling grid and the locations flow gauges used for calibration) and major reservoirs within the Cauvery Basin and the Narmada Basin.

\subsection{Model Improvement}

There was a need to extend the representation of processes and stores in the GWAVA model to better represent water resources, However, it was necessary to improve the model without excessively increasing the model complexity and input data requirements.

\subsubsection{Representing groundwater processes}

AMBHAS-1D [53] is a spatial groundwater model that determines a daily groundwater level based on equations from McDonald \& Harbaugh (1988) [54]. AMBHAS-1D implements distributed transient groundwater modelling. The model is based on the groundwater flow equation solved numerically, using the finite-difference explicit scheme [55]. The implementation of various AMBHAS versions in India was shown to be highly successful in simulating groundwater levels across areas of Karnataka [56], in the Barembadi catchment [57, 58] and an idealised system based on the Ganges River [10]. Additionally, de Bruin et al. (2012) [59] utilised the results generated from AMBHAS-1D to guide the set of SWAT groundwater parameters for use in the Jaldhaka Basin. The successful application of AMBHAS-1D highlighted its suitability in India and other regions with low data availability.

In line with the AMBHAS-1D conceptualisation, additional groundwater processes have been incorporated into GWAVA through the full coupling of the recharge, streamflow, water abstractions and base flow (Error! Reference source not found.). The groundwater store was conceptualised as a vertically layered aquifer. Each layer was allocated a 
specific yield and depth and can vary from cell-to-cell based on data available pertaining to the local hydrogeology. The aquifer can be recharged from soil moisture, the bottom of lakes, reservoirs, and small scale recharge interventions, and leaking via the water supply infrastructure. Water can be directly abstracted from the aquifer to its maximum depth. The groundwater contribution to baseflow (BF) was calculated as follows:

$B F=\left\{\begin{array}{rr}\gamma \times\left(G W_{\text {store }}-G W_{B F}\right), G W_{\text {store }}>G W_{B F} \\ 0, \quad G W_{\text {store }} & \leq G W_{B F}\end{array}\right.$

where $\gamma$ is a routing coefficient, $\mathrm{GW}_{\text {store }}$ is the groundwater store and $\mathrm{GW}_{\mathrm{BF}}$ is the level of groundwater storage below which there is no baseflow. GW $\mathrm{BF}$ can be converted to an aquifer depth below ground level by dividing by the specific yield.

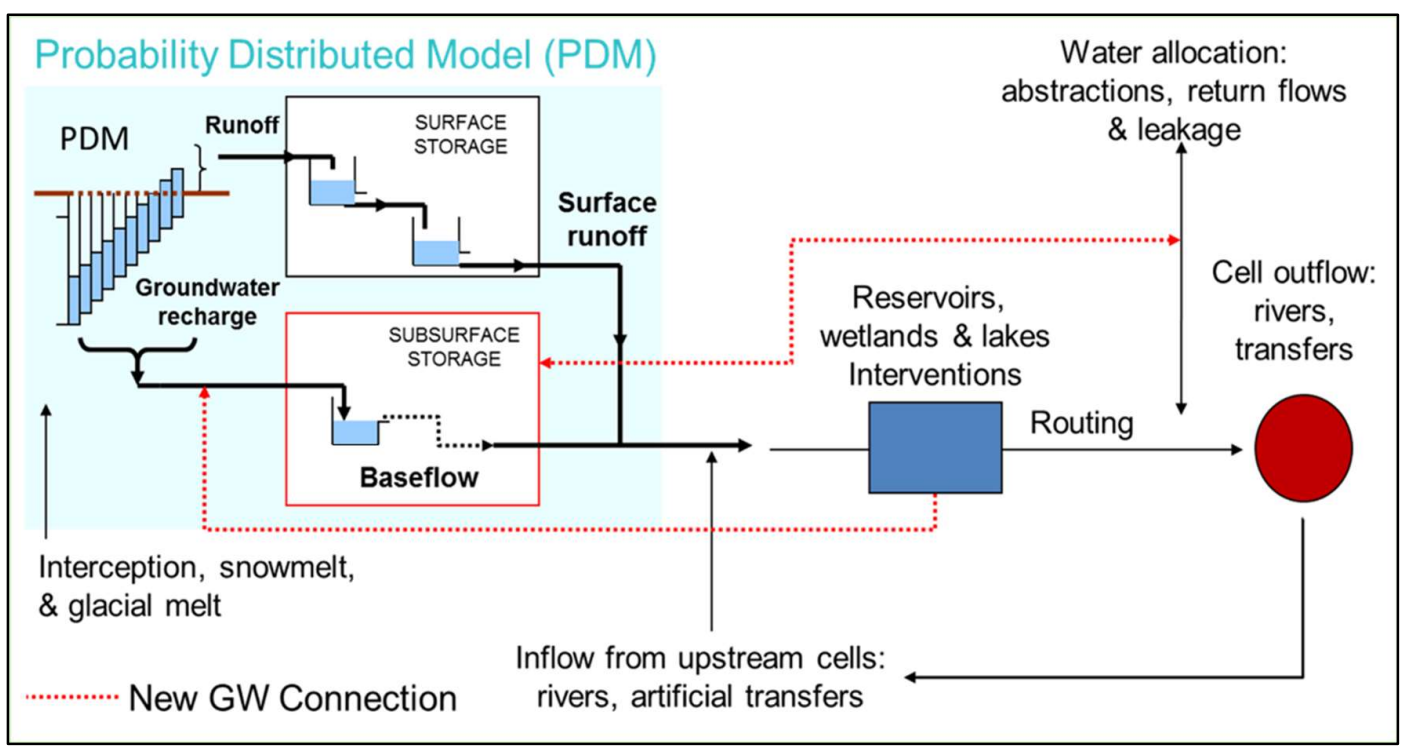

Figure 2. Schematic of the new groundwater connections and feedbacks included in the GWAVA model [60].

The implementation of the fully coupled groundwater functionality with GWAVA is flexible. The necessary input is limited to the specific yield and aquifer depth. In areas where data is limited, the aquifer characteristics can be agglomerated into a single layer, whereas, in regions with more comprehensive data the aquifer can be divided into more layers (with no upper limit).

\subsubsection{Regulated reservoirs}

In practice, reservoir operating rules are normally based on the specifications of each reservoir, the hydrometeorological conditions of the basin, and the water demand downstream. Hanasaki et al. (2006) [61] developed an algorithm to approximate reservoir operating rules within global hydrological and land-surface models. The algorithm reflects these parameters and can be implemented with currently available global datasets (reservoir dimensions and purpose, simulated inflow, river discharge, water use, etc.).

The reservoir operation scheme is a valuable tool in regions where specific data about the reservoir characteristics of the outflow volumes is not available. The algorithm consists of two equations. The first is used when a consistent reservoir release is expected (i.e. when used for hydropower or to meet domestic demand), and the second is for a seasonal release (i.e. when used for irrigation).

For consistent release reservoirs, the operating rules are set to minimize inter-annual and seasonal reservoir releases. Hanasaki et al. (2006) [61] presents the equations as follows. 0.5 :

When the reservoir capacity divided by the mean annual inflow (c) is greater than 


$$
r=\frac{s_{\text {ini }}}{0.85 C} \times i_{\text {mean }}
$$

When the reservoir capacity divided by the mean annual inflow(c) is less than or equal to 0.5:

$$
r=\left(\frac{C}{0.5}\right)^{2} \times \frac{S_{\text {ini }}}{0.85 C} \times i_{\text {mean }}+\left[1-\left(\frac{C}{0.5}\right)^{2}\right] \times i
$$

Where $r$ is the simulated reservoir release $\left(\mathrm{m}^{3} / \mathrm{s}\right), S_{\text {ini }}$ is the simulated storage at the beginning of the operational year $\left(\mathrm{m}^{3}\right), \mathrm{C}$ is the user input reservoir capacity $\left(\mathrm{m}^{3}\right)$, imean is the simulated mean annual inflow $\left(\mathrm{m}^{3} / \mathrm{s}\right)$ and, $i$ is the simulated daily inflow $\left(\mathrm{m}^{3} / \mathrm{s}\right)$.

This algorithm has been successfully incorporated into H08 [62] and influenced the reservoir routines of WATERGAP [1] and LPJmL [23]. The scheme is simple and designed primarily to represent inter-annual and monthly fluctuations in reservoir release. This approach has been demonstrated to be largely valid, but because reservoir operations are highly complex and tend to be based on human decisions, there is inevitably a level of uncertainty associated with its application.

The two new reservoir equations added to the GWAVA model are a simplified version of the Hanasaki equations [61], while the existing reservoir routine is maintained as an option [5]. Since GWAVA can account for irrigation water demand within the transfers' routine, the equations for consistent reservoir release have been implemented. In the original Hanasaki equation, $i_{\text {mean }}$ was calculated as the mean inflow over all simulated years, as $S_{i n i}$ accounted for inter-annual variability. In equation $5, i_{\text {mean }}$ has been changed to reflect the yearly mean inflow to introduce inter-annual variability. 0.5 :

When the reservoir capacity divided by the mean annual inflow (c) is greater than

$$
r=\alpha \times i_{a m}
$$

When the reservoir capacity divided by the mean annual inflow (c) is less than or equal to 0.5:

$$
r=\alpha \times \beta \times i_{a m}+[1-\beta] \times i
$$

Where $i_{a m}$ is the mean yearly inflow $\left(\mathrm{m}^{3} / \mathrm{s}\right)$ and $\alpha$ and $\beta$ are user-set parameters between $0-1$, replacing $\frac{S_{i n i}}{0.85}$ and $\left(\frac{C}{0.5}\right)^{2}$ from the original Hanasaki equations, respectively.

The user-set parameters can be manually calibrated to best fit either the observed streamflow at the next downstream gauging point of the reservoir, or the reported reservoir outflow data. The addition of the regulated reservoir routine includes an additional two calibratable parameters $(\alpha$ and $\beta$ ) and thus does not increase the input data required to incorporate this routine.

\subsection{Data Acquisition}

Input data were collected from several sources and extracted from global and regional datasets. The sources and details of the data used in this modelling exercise can be found in Table A1 and A2 in Appendix A.

\subsection{Model Setup}

The Cauvery and Narmada Basins were modelled at a spatial scale of 0.125 degrees using four versions of the GWAVA model.

- GWAVA- the original version of GWAVA [5]

- GWAVA-GW- the original version of GWAVA with groundwater coupling 
- GWAVA-Res - the original version of GWAVA with the regulated reservoirs

- GWAVA 5.1- the original version of GWAVA with both the groundwater coupling and regulated reservoirs

A thirty-year simulation period of 1981 to 2010 was chosen. The Cauvery and Narmada Basins were disaggregated into 444 and 653 modelling cells, respectively. Both basins included domestic, irrigation and livestock demand (with the inclusion of industrial demand limited to the Cauvery due to data limitations in the Narmada), large-scale water transfers, hydropower reservoirs, irrigation reservoirs and agriculture within the command and rural areas.

\subsection{Model Calibration}

Several calibration gauges were included within each basin: 14 in the Cauvery and 13 in the Narmada (Figure 1). Simulated streamflow was calibrated against observed streamflow using the SIMPLEX auto-calibration routine. This routine utilises four parameters (a surface and groundwater routing parameter, a PDM parameter that describes spatial variation in soil moisture capacity, and a multiplier to adjust rooting depths). The calibration gauges were selected based on the completeness of the data, time period of the data, and size of the sub-catchment. The observed data was deemed sufficient when more than $50 \%$ of the values were identified as 'observed' and not 'computed', and had at least five consecutive years available from 1981 until 2010. Additionally, sub-catchments smaller than $800 \mathrm{~km}^{2}$ (six GWAVA grid cells) were nested into the larger sub-catchment in which they are located.

The reservoir outflow parameters were manually calibrated. Error! Reference source not found. presents the parameters for each reservoir that provided the best fit to either observed outflow data, where available, or downstream observed streamflow. 
Table 1. Reservoir outflow parameters determined by a manual calibration for each major reservoir in the Cauvery and Narmada basins.

\begin{tabular}{|c|c|c|c|c|c|c|c|}
\hline Reservoir & Basin & $\begin{array}{c}\text { Capacity }\left(10^{9}\right. \\
\left.\mathrm{m}^{3}\right)\end{array}$ & $\begin{array}{c}\text { Simulated av- } \\
\text { erage annual } \\
\text { inflow (10 } \\
\left.\mathrm{m}^{3} / \text { year }\right)\end{array}$ & c & Equation & $\alpha$ & $\beta$ \\
\hline Hemavathy & Cauvery & 0.99 & 0.22 & 0.45 & 5 & 0.7 & 0.8 \\
\hline Krishna Raja Sagara (KRS) & Cauvery & 1.016 & 0.35 & 0.29 & 5 & 0.7 & 1 \\
\hline Kabini & Cauvery & 0.44 & 0.15 & 0.29 & 5 & 0.1 & 1 \\
\hline Bhavanisagar & Cauvery & 0.791 & 0.09 & 0.86 & 4 & 1 & \\
\hline Mettur & Cauvery & 2.64 & 0.70 & 0.38 & 5 & 1 & 0.1 \\
\hline Bargi & Narmada & 3.18 & 0.32 & 1.01 & 4 & 0.3 & \\
\hline Barna & Narmada & 0.539 & 0.21 & 0.26 & 5 & 0.3 & 0.3 \\
\hline Tawa & Narmada & 2.313 & 0.27 & 0.86 & 4 & 0.3 & \\
\hline Indira Sagar Project (ISP) & Narmada & 10 & 3.03 & 0.33 & 5 & 0.1 & 1 \\
\hline $\begin{array}{c}\text { Omkareshwar Sagar Project } \\
\text { (OSP) }\end{array}$ & Narmada & 0.987 & 1.40 & 0.07 & 5 & 0.1 & 1 \\
\hline Sardar Sarovar Project (SSP) & Narmada & 9.5 & 3.69 & 0.26 & 5 & 0.5 & 0.3 \\
\hline Karjan & Narmada & 0.63 & 3.89 & 0.02 & 5 & 0.1 & 0.3 \\
\hline
\end{tabular}

\section{Model Evaluation}

Due to the high variability of streamflow in both the Cauvery and Narmada basins, several different metrics are used to quantify the model performance under various flow regimes. In this study, the Kling- Gupta Efficiency (KGE) was used to determine the models' ability to represent the entirety of the hydrograph, the Nash-Sutcliffe Efficiency (NSE) to determine the model performance in representing the high flow periods, the LogNash Efficiency (LNE) was used to determine the model's performance in representing the low flow periods, and the bias was used to evaluate the model ability to estimate the total volume of streamflow across the modelling period. The change in model skill was utilised to compare the performance of two model configurations (GWAVA and GWAVA-GW, GWAVA and GWAVA-Res, and GWAVA and GWAVA 5.1).

\subsection{Kling-Gupta Efficiency (KGE)}

The KGE is based on correlation, variability bias and mean bias, and is calculated as:

$$
K G E=1-\sqrt{(r-1)^{2}+\left(\frac{\sigma_{s}}{\sigma_{o}}-1\right)^{2}+\left(\frac{\mu_{s}}{\mu_{o}}-1\right)^{2}}
$$

where $r$ is the correlation coefficient between simulated and observed data, $\sigma_{o}$ is the standard deviation of observation data, $\sigma_{s}$ is the standard deviation of simulated data, $\mu_{0}$ is the mean of observation data and $\mu_{s}$ is the mean of simulated data.

The KGE indicates the overall performance of the model. The metric allows some perceived shortcomings with NSE to be overcome and has become increasingly popular for the evaluation of hydrological model skill. A KGE of one indicates perfect agreement between simulations and observations. However, there are many opinions as to where the differentiation of 'good' and 'poor' model performance thresholds lies within the KGE scale. Negative KGE values do not always imply that the model performs worse than the mean flow benchmark. For this study, and to be able to compare model performance, a KGE score of less than 0.2 was deemed poor, between 0.2 and 0.6 as fair and above 0.6 as good.

\subsection{Nash-Sutcliffe Efficiency (NSE)}

NSE is a popular metric to evaluate hydrological model performance because it aims to normalise model performance into an interpretable scale, and was calculated as: 


$$
N S E=1-\frac{\sum_{t=1}^{T}\left(Q_{S}^{t}-Q_{o}^{t}\right)^{2}}{\sum_{t=1}^{T}\left(Q_{o}^{t}-\overline{Q_{o}}\right)^{2}}
$$

where $Q_{s}^{t}$ and $Q_{o}^{t}$ are, respectively, the simulated streamflow, and the observed streamflow at timestep $t ; \overline{Q_{o}}$ is the average observed streamflow over all timesteps considered.

An NSE of one represents a perfect correspondence between the simulations and the observations. An NSE of zero indicates that the model simulations have the same explanatory power as the mean of the observations. An NSE of less than zero represents that the model is a worse predictor than the mean of the observations. However, NSE does not provide an equal benchmark for different flow regimes. Utilising the single NSE metric is not sufficient for determining the performance of a model, however, it can provide context if utilised in conjunction with additional model performance efficiencies. For this study, an NSE score of less than 0.2 was deemed poor, between 0.2 and 0.6 as fair and above 0.6 as good.

\subsection{Log-Nash Efficiency (LNE)}

LNE is often used for model evaluation when low-flow performance is of importance, and was calculated as:

$\mathrm{LNE}=1-\frac{\sum_{t=1}^{T}\left(Q_{s_{l} \log }^{t}-Q_{o_{l}}^{t} \log \right)^{2}}{\sum_{t=1}^{T}\left(Q_{o_{-}}^{t} \text { log }-\overline{Q_{o_{-} l o g}}\right)^{2}}$

with:

$Q_{S_{-} \log }^{t}=\log _{10}\left(Q_{S}^{t}+c\right)$

$Q_{o_{-} \log }^{t}=\log _{10}\left(Q_{o}^{t}+c\right)$

where $Q_{S_{-} l o g}^{t}$ and $Q_{o_{-}}^{t} \log$ are, respectively, the log of simulated streamflow, and the log of observed streamflow at timestep $t ; \overline{\boldsymbol{Q}_{\boldsymbol{O}} \log }$ is the average of log observed streamflow over all timesteps considered. $c$ is a positive constant equal to the 10th percentile of the observed flow. The use of the constant $c$ reduced emphasis on very small flows, which tend to be unreliable, and avoids numerical problems with attempting to calculate the logarithm of zero flows. The LNE was interpreted in the same way as for the NSE.

\subsection{Bias}

The bias is the average tendency of the simulated data to over-or under-estimate the observed data (Equation 10). The optimal value for the bias is zero. Positive values indicate a model under-estimation and negative values indicate an over-estimation. When assessing a model's ability to simulate streamflow, the bias indicates the ability of the model to predict the overall streamflow volume across the modelling period.

$$
\text { Bias }=\frac{\sum_{t=1}^{T}\left(y_{o}-y_{s}\right)}{\sum_{t=1}^{n} y_{o}} \times 100
$$

where $y_{0}$ is the observed data value, $y_{s}$ is the simulated data value and $t$ is the time-step.

\subsection{Model skill}

The change in model skill, $\Delta$ skill, between the different model configurations for streamflow prediction was calculated as follows:

$\Delta$ skill $=\frac{R_{2}-R_{1}}{R_{\text {optimal }}-R_{1}}$ 
where $R_{1}$ and $R_{2}$ are the efficiency value for the two model configurations being compared and Roptimal is the best possible efficiency value for a given metric. A positive value of $\Delta$ skill indicates that model configuration two performs better than model configuration one, a zero value suggests similar performance, and a negative value shows that model configuration two performs less well than model configuration one.

\section{Results}

\subsection{Streamflow}

The ability of the four model versions to predict the observed streamflow was presented through the monthly KGE at each gauging station (Error! Reference source not found.), to demonstrate the model's overall performance and an indication of the model skill in representing the low flows (Figures 3 and 4). The monthly bias, NSE, KGE and LNE values for each sub-catchment for each model version can be found in Table 1D in Appendix D.

The model performance was generally higher in the Narmada compared to the Cauvery. In the sub-catchments of the Cauvery and Narmada, GWAVA 5.1 outperforms GWAVA. However, the performance of GWAVA-GW and GWAVA-Res varies between the sub-catchments. As expected, in sub-catchments without major reservoirs, GWAVA produced the same results as GWAVA-Res, and GWAVA-GW produced the same results as GWAVA 5.1.

All the simulated flows for the sub-catchments in the Narmada are classified as good in performance, except for the simulation of Belkeri without the groundwater routine, which was classified as fair (Error! Reference source not found.). In the Cauvery the results are more varied, with eight sub-catchments classified as good and six sub-catchments as fair when using GWAVA 5.1. The performance of the downstream sub-catchments without the combination of groundwater and the regulated reservoir routine falls within the fair range (Error! Reference source not found.).

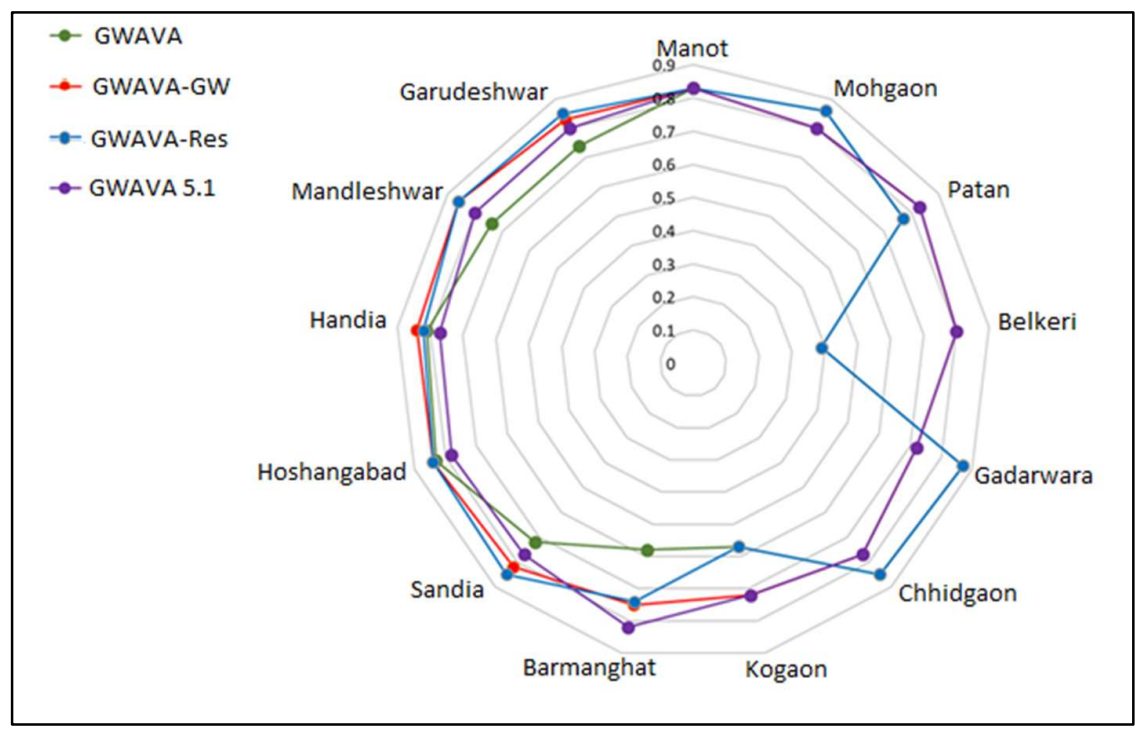

Figure 3. A representation of the monthly KGE values obtained for each model at each gauging station within the Narmada Basin. The values on the y-axis represent the KGE value. 


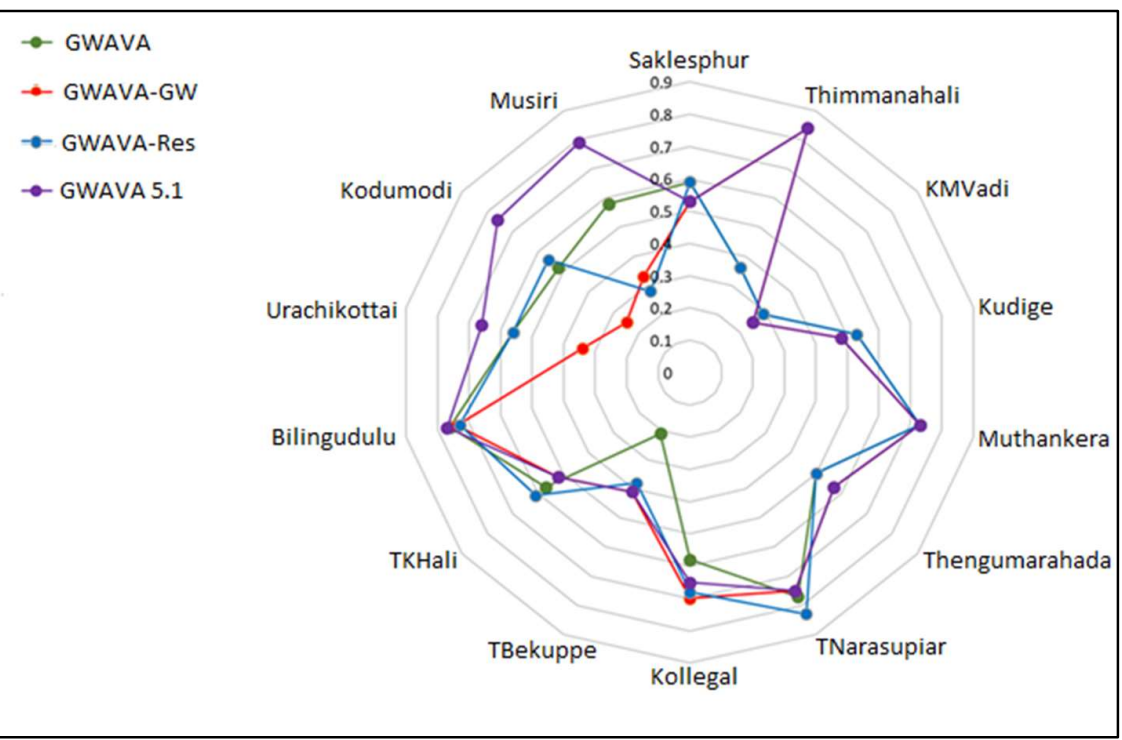

Figure 4. A representation of the monthly KGE values obtained for each model at each gauging station within the Cauvery Basin. The values on the y-axis represent the KGE value.

The ability of the model to represent the low flow periods well is critical in basins that suffer from water scarcity. In the Cauvery Basin, the aggressive pumping of groundwater limits the baseflow released from the groundwater store to sustain the streamflow in the dry season, and the large reservoirs store and release water in contrast to the seasonal patterns. The inclusion of groundwater feedbacks into GWAVA improves the simulation of the low flows within the headwater sub-catchments, which is critical for the assessment of water resources as well as surface water-groundwater interactions (Error! Reference source not found.iii). The incorporation of the regulated reservoir module allows for the release of water in the dry season. This markedly improves the simulation downstream of these major reservoirs in the Cauvery (Error! Reference source not found.ii). The combination of the groundwater processes and inclusion of the regulated reservoirs improves the ability of GWAVA to represent the low flows throughout the ba$\sin$ (Error! Reference source not found.i). 

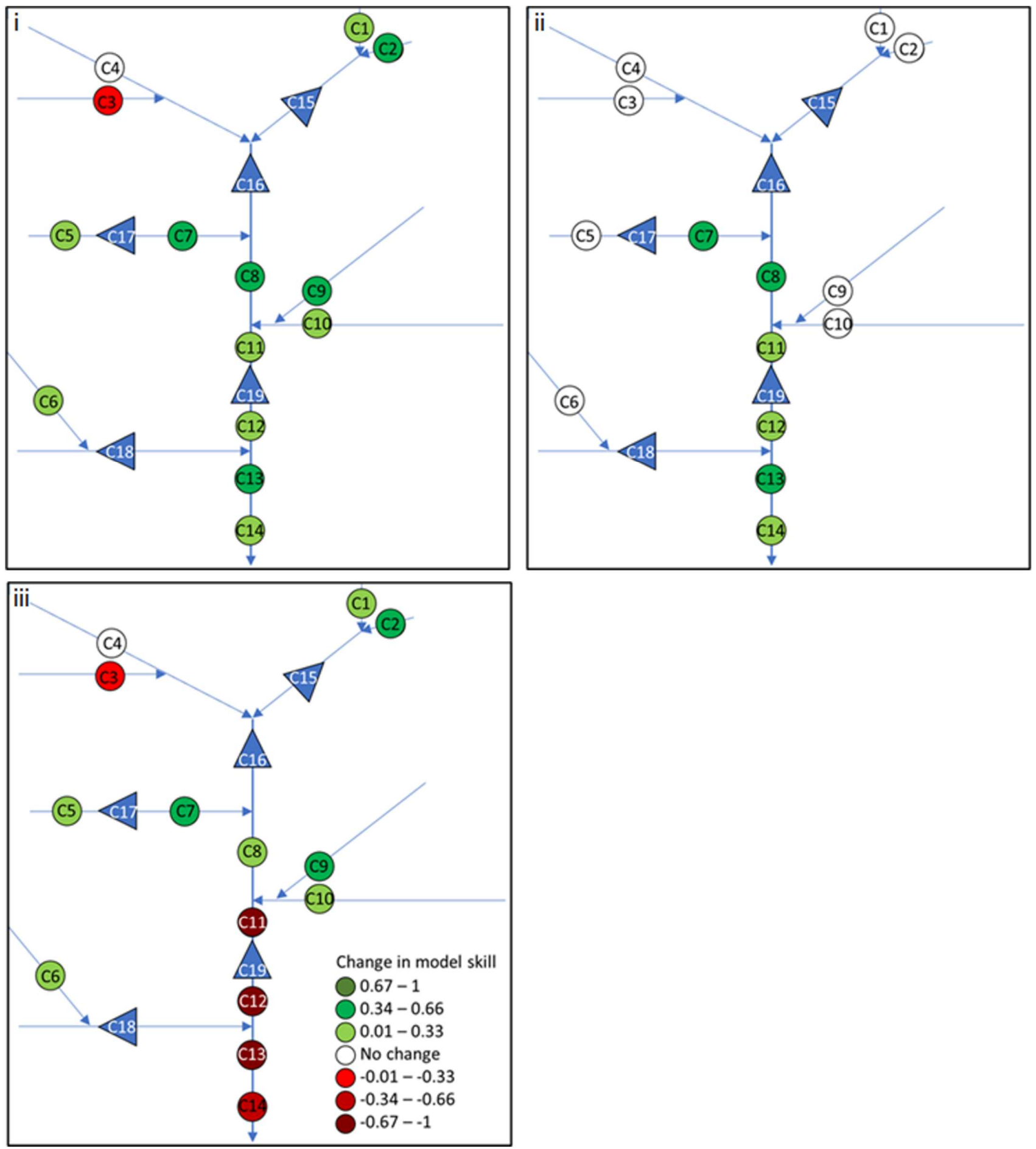

Figure 5. A representation of the low flow model skill for each sub-catchment in the Cauvery Basin for the i) GWAVA 5.1, ii) GWAVA-Res and iii) GWAVA- GW versions, compared to GWAVA.

The Narmada River is primarily groundwater-fed following the monsoon season. Understanding the baseflow contribution to streamflow and the impact that the large reservoirs have on the dry season flow poses a challenge for water managers. The inclusion of the groundwater module improves the model's representation of the low flows within the headwater sub-catchments (Error! Reference source not found.iii). The inclusion of the groundwater processes allows the model to better retain water within the groundwa- 
ter store and release baseflow throughout the year. The large reservoirs within the Narmada consistently release water through the hydropower plants, and thus the incorporation of the regulated reservoir routine allows the model to release water from the reservoirs throughout the year. This produces a better match to the observed low flow data periods compared to results using the original GWAVA reservoir routine (Error! Reference source not found.ii). The duel incorporation of the groundwater processes and the regulated reservoir routine provides a better representation of the low flow periods across the basin (Error! Reference source not found.i).
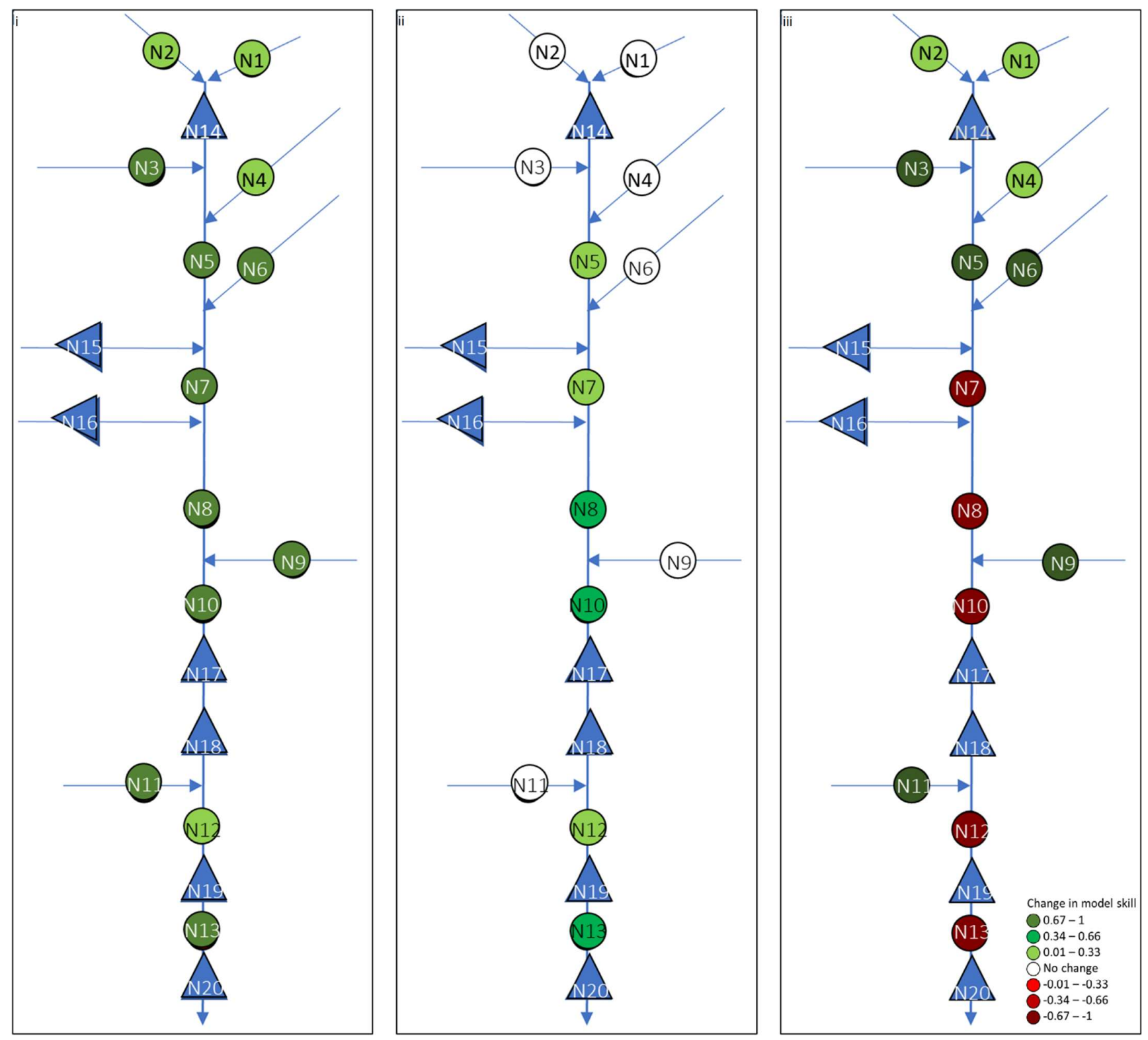

Figure 6. A representation of the low flow model skill for each sub-catchment in the Narmada Basin for the i) GWAVA 5.1, ii) GWAVA-Res and iii) GWAVA-GW versions compared to GWAVA.

\subsection{Groundwater}

The average observed depth to groundwater (measured from ground level) is deeper in the Cauvery than in the Narmada (Error! Reference source not found.). In the Cauvery, the wetter, more pristine sub-catchments along the western boundary (Western Ghats) have a shallower observed groundwater level (5 to 10 meters below ground level), while 
the groundwater level deepens (11 to 35 meters below ground level) throughout the remainder of the basin. In the Cauvery, GWAVA 5.1 can represent the shallower groundwater levels with higher accuracy compared to the deeper levels, however, it systematically overestimates the depth to groundwater throughout the basin.

The average observed groundwater depth within the Narmada basin is no deeper than 10 meters below the ground level. GWAVA 5.1 can represent the average groundwater levels well throughout the sub-catchments, with the observed average differing a maximum of two meters from the simulated average in the most downstream sub-catchment. The representation was more accurate in the upstream sub-catchments where the water table is shallower and the landscape is more pristine.

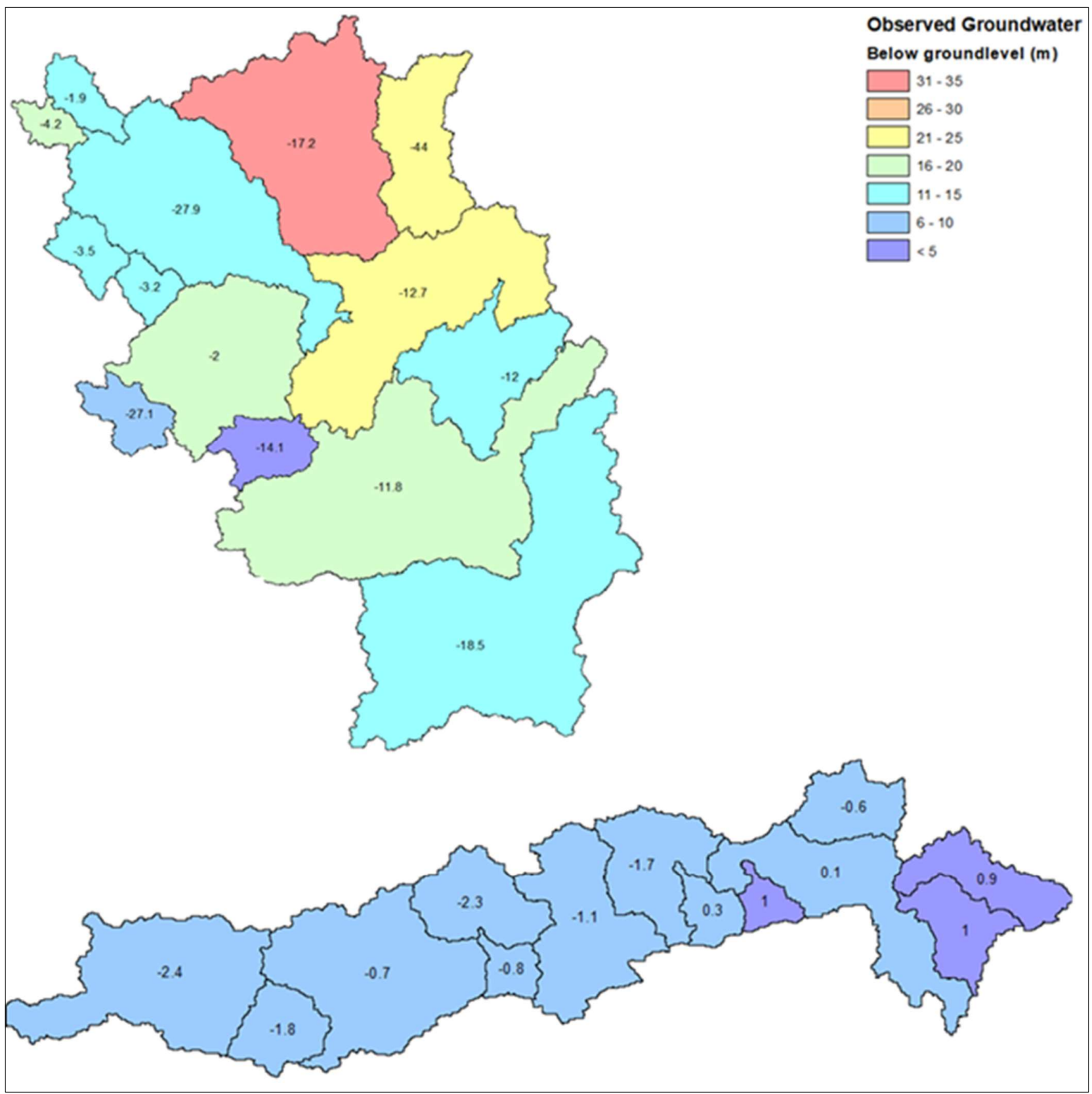

Figure 7. The average observed groundwater levels below ground level, and the difference between the observed and GWAVA 5.1 simulated groundwater levels in meters from 1981 to 2010 for the Narmada and Cauvery sub-catchments.

\subsection{Reservoirs}


In the Narmada, GWAVA represents the daily reservoir releases well but overestimates the total volume of water released at Bargi, Tawa and SSP (Error! Reference source not found.). The inclusion of the regulated reservoir routine in the Narmada did not significantly improve the daily release representation but did improve the total volume of water being released. In the Cauvery, GWAVA represents the daily releases well at Kabini and KRS but poorly at Mettur. The total volume of water released from the major reservoirs in the Cauvery are underestimated. When applying the regulated reservoir routine, the daily releases and total volume of water released are significantly improved (Error! Reference source not found.).

Table 2. The percent bias and daily Nash-Sutcliffe Efficiency (NSE) at the outlets of the major reservoirs for GWAVA and GWAVA-Res.

\begin{tabular}{ccccc}
\hline \multirow{2}{*}{ Reservoir Outlet } & \multicolumn{3}{c}{ Bias (\%) } & \multicolumn{2}{c}{ Daily NSE } \\
\cline { 2 - 5 } & GWAVA & GWAVA-Res & GWAVA & 0.53 \\
Bargi & 17.8 & 3.2 & 0.74 & 0.62 \\
Tawa & 7.57 & 0.4 & 0.62 & 0.7 \\
SSP & 16.09 & 4.35 & 0.37 & 0.65 \\
Kabini & -13.45 & 3.64 & 0.38 & 0.52 \\
KRS & -33.69 & -15.43 & -0.25 & 0.39 \\
Mettur & -4.69 & 9.35 & &
\end{tabular}

The application of the regulated reservoir routine better represents the annual reservoir releases throughout the observational time period at Kabini, Tawa, KRS and SSP (Error! Reference source not found.). At Bargi, GWAVA-Res simulates the normal and dry years better than GWAVA but underestimates the annual releases in wet years (Error! Reference source not found.). The annual releases are improved until 1995 at Mettur dam but following 1995, GWAVA-Res has a better temporal pattern and GWAVA a better representative release volume (Error! Reference source not found.). Although the annual volume at Mettur was better represented by GWAVA, at the daily scale, GWAVA-Res can capture the regulated reservoir pattern significantly better than GWAVA (Error! Reference source not found.).

GWAVA 5.1 represents the daily reservoir capacity during the monsoon period well at Tawa and SSP. The model was depleting the reservoir storage through irrigation demand during the dry seasons, which was not reflected in the observed data. The filling and release temporal pattern was good at Tawa, accurately reflecting the observational data (Error! Reference source not found.). At SSP the model tends to reach full capacity and begin releasing water earlier in the monsoon season than suggested by the observed data (Error! Reference source not found.). At KRS, the observed data shows a depletion or near-depletion of the reservoir storage during the dry season. The model, however, was overestimating the volume of water remaining in the reservoir during these times. GWAVA 5.1 does not capture the 2002-2003 drought period particularly well in the upper regions of the basin (Error! Reference source not found.). At the Mettur Dam, the model produces a satisfactory temporal pattern, however, it over-estimates the volume in the dry season and under-estimates in the monsoon season. The 2002-2003 drought was better captured by the model at this reservoir compared to the upper regions of the basin (Error! Reference source not found.). 

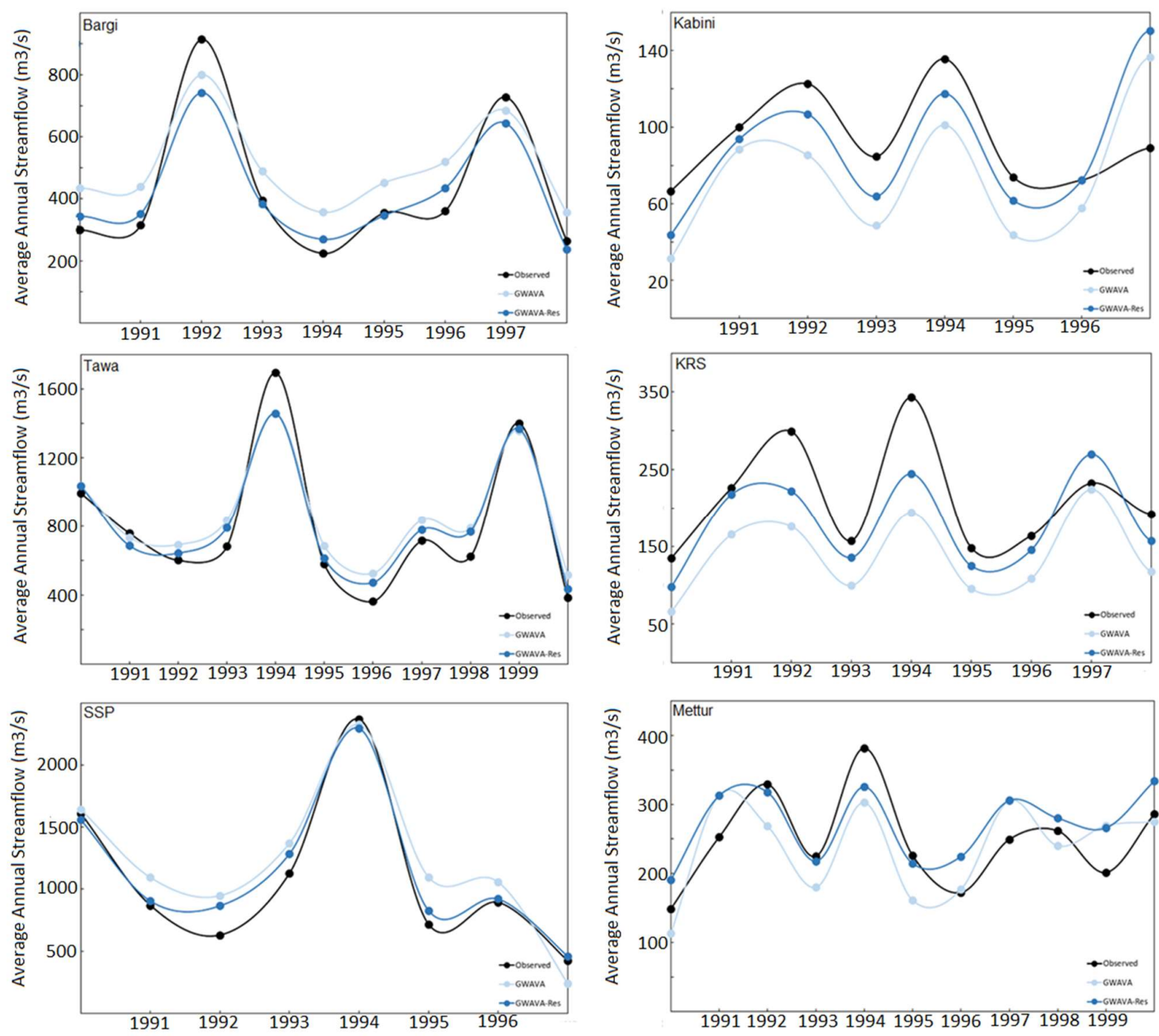

Figure 8. The average annual observed and GWAVA and GWAVA-Res simulated reservoir releases at the outflow of Bargi, Tawa, SSP, Kabini, KRS and Mettur reservoirs. 


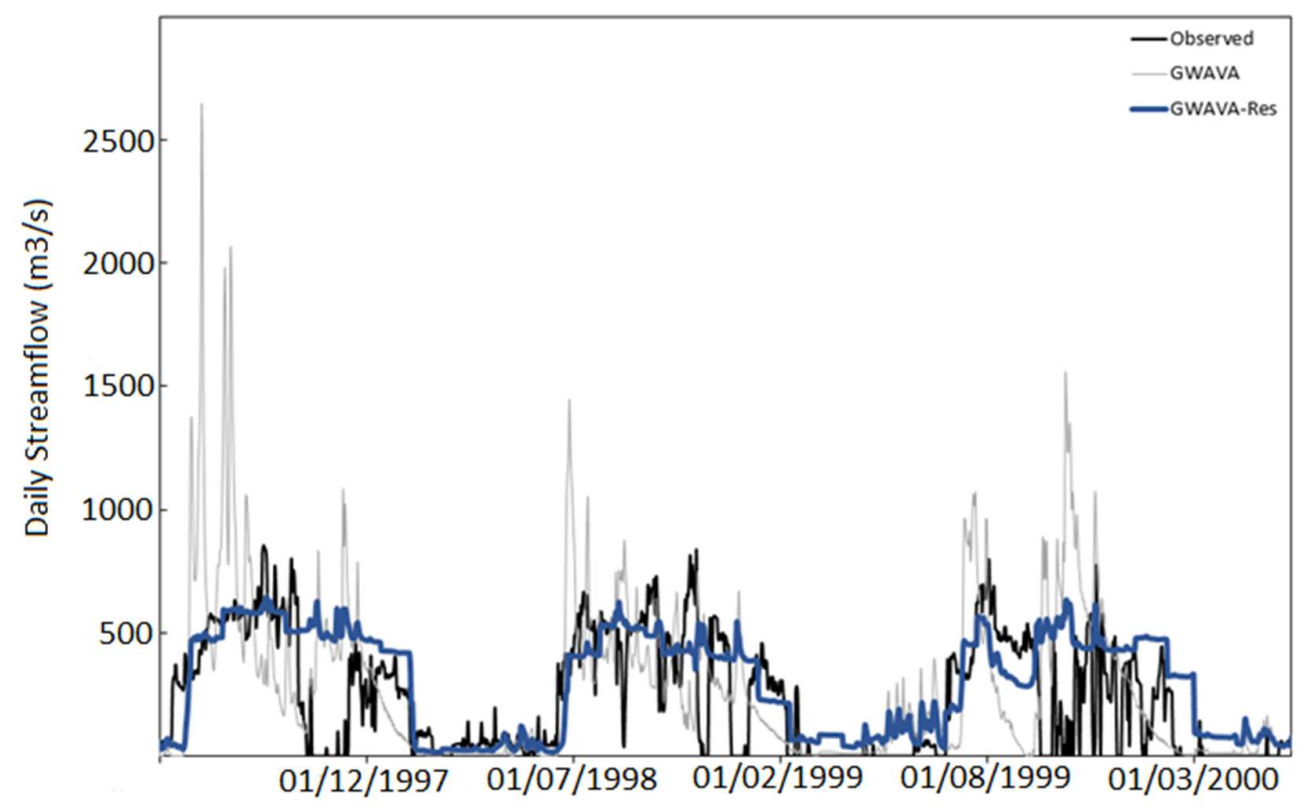

Figure 9. The daily observed and GWAVA and GWAVA-Res simulated reservoir outflows at the outflow of Mettur Dam.
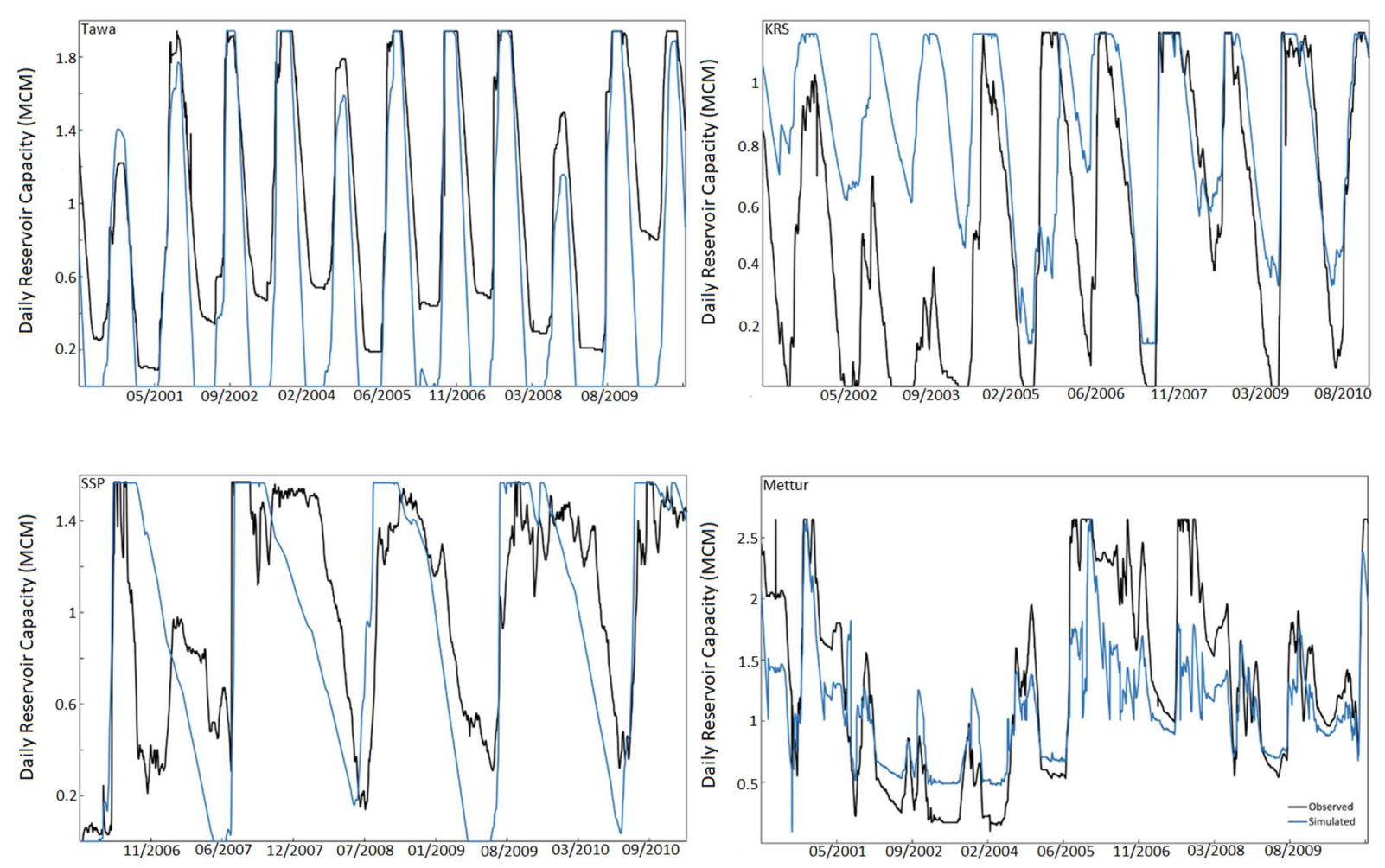

Figure 10. The observed and GWAVA 5.1 simulated daily reservoir storage in million cubic meters for Tawa, KRS and Mettur, and billion cubic meters for SSP across varying periods for which observed data were available.

\section{Discussion}

The revision of the groundwater routine allows for the traceability of recharge, baseflow, groundwater levels and volume of abstraction from groundwater resources. The regulated reservoir routine allows for a release from the major reservoirs throughout the year and the output of reservoir storage capacity throughout the simulation period. 
The improved groundwater and reservoir routines were included in the GWAVA model, with the addition of three and two input parameters respectively.

The inclusion of the revised groundwater routine improved the simulation of streamflow in the headwater catchments, while the new reservoir routine improved the simulation of streamflow in catchments downstream of major reservoirs in both the Cauvery and Narmada. The regulated reservoir routine improves both the timing and volume of releases from major reservoirs. In line with GWAVA 5.1, revisions to the reservoir routines in SWAT [63], DHSVM [64], VIC [65], MESH [25] and HYPE [26] improved representation and parameterization of major operational reservoir outflows, illustrating that such revisions in large-scale models can be of benefit to both the temporal and volumetric simulation of streamflow downstream of reservoirs. GWAVA 5.1 can track the reservoir capacity throughout the simulation period. In the Narmada, the seasonality and filling of Tawa and SSP are represented well, however, the model was drying out the reservoirs each year, which was not reflected in reality. It is therefore necessary to introduce a user-defined limit into the reservoir routine to restrict extraction and release below a realistic reservoir level. In the Cauvery, at KRS, the opposite was occurring. The observed reservoir levels are reducing to empty each year, but the model was simulating water in the reservoirs during this time. At the Mettur Dam, the daily reservoir capacity was highly sensitive to the volume of inflow. Although the temporal pattern was adequate, the model was overestimating the volume of water in the reservoir during the dry season but underestimating the volume during the monsoon season.

The streamflow in the Narmada is primarily base flow fed [66], and groundwater pumping is limited to periods of drought. The groundwater tends to fluctuate within ten meters of the ground level. The model accurately represented the average groundwater depth within two meters of the observed average over the simulation period. The inclusion of more comprehensive groundwater processes within the model structures allows for a more accurate simulation of the hydrograph within the Narmada, especially during the dry season.

Thomas et al., (2021) [66] applied SWAT in the Upper Narmada. This study allowed for irrigation demands to be met from shallow and deep aquifer stores. The reservoir simulation required the engineering particulars of the reservoir and inflows into the reservoir to estimate probable flow at $50 \%, 75 \%$ and $90 \%$ dependability for different months. In the headwater catchments, GWAVA and GWAVA 5.1 outperform SWAT in the prediction of streamflow. The original and revised groundwater routines with the original reservoir equation perform well within these catchments where the reservoirs are small and the steep topography results in the overland flow being the dominant streamflow generation process. At Barmanghat, downstream of Bargi Dam (regulated reservoir) and with a larger base flow contribution, SWAT performs better than GWAVA, but with the inclusion of the more comprehensive groundwater and regulated reservoirs, GWAVA 5.1 performs better than SWAT.

Goswami and Kar (2018) [67] represented the full extent of the Narmada basin using a version of SWAT where groundwater flow contribution to streamflow was simulated by routing through a shallow aquifer store, but with no considerations for reservoirs within the basin. GWAVA-GW and GWAVA 5.1 significantly outperform SWAT in streamflow prediction at Garudeshwar. Pechlivanidis and Arheimer (2015) [68] applied India-HYPE in the Narmada basin using a 15-parameter reservoir routine and a comprehensive, multi-parameter, groundwater routine. All the versions of GWAVA presented in this study outperform India-HYPE at Garudeshwar. The average groundwater depth estimations by GWAVA 5.1 in the Hoshangabad district of Madhya Pradesh are consistent with those simulated using a conceptual groundwater model by Nema et al., (2019) [69].

The satisfactory performance of GWAVA 5.1 to represent streamflow, groundwater levels and reservoir fluxes throughout the basin, compared with observed data and existing literature, demonstrates the value of the simple, low input routines incorporated into GWAVA. Therefore, the inclusion of groundwater processes and regulation reservoirs 
was justified when modelling basins with natural and anthropogenic characteristics similar to that of the Narmada.

In the upper regions of the Cauvery, ANN [32, 70], SWAT [34] and VIC [34] outperform both GWAVA and GWAVA 5.1, although the performance of GWAVA was improved when the groundwater routine was applied to this region. GWAVA 5.1 underestimated the aquifer level across the basin. Collins et al., (2020) [71] showed largely under-simulated groundwater levels compared to the observed data in the Berambadi subcatchment of the Cauvery using a one-dimensional numerical transect model. It was suggested that a poor representation of the IMD rainfall in this region may be a critical part of the poor simulations of both recharge to groundwater and streamflow in this region [33].

The one-dimensional groundwater representation may not represent the groundwater processes in regions with highly depleted aquifers and gneiss geomorphology adequately. In turn, the under-estimation of the groundwater levels and subsequent base flow component hinders the ability of the model to accurately represent the streamflow. There was low confidence in the data with regards to pumping depth and observed groundwater level data in this region [30,72]. These uncertainties can result from difficulties in the estimation of area-averaged groundwater storage from point observations of groundwater levels, and inconsistency in spatial and temporal records of groundwater levels.

GWAVA 5.1 potentially overestimates the water withdrawals in basins, particularly in the Cauvery, where the exact anthropogenic water use was uncertain and poorly documented. Major uncertainties are generated from the quantification of water withdrawals, especially from irrigation and industrial users. Data with regards to water use from these sections was very often either modelled or estimated [30]. The addition of three calibratable parameters for the reservoir release function and groundwater processes increases the uncertainty concerning model equifinality [73].

When improving a low data input hydrological model, such as GWAVA, caution must be taken to not complicate the model beyond its underlying capability. The improvements to GWAVA utilizing simple modified routines demonstrate that adapting existing hydrological models can be suitable for the improvement in the reliability of streamflow, reservoir and groundwater prediction.

\section{Conclusions}

Robust simulations of groundwater availability and reservoir storage and releases are important for water resources management in semi-arid basins where groundwater was an important water source during the dry season, and the streamflow in the main channel of the lower reaches was largely reservoir-regulated. This paper describes the extension of the GWAVA model to include one-dimensional groundwater and a regulated reservoir routine. As a result of applying the original GWAVA model alongside three modified versions, it was found that the inclusion of the revised groundwater routine improved the simulation of streamflow in the head-water catchments, whilst the new reservoir routine improved the simulation of streamflow in catchments downstream of major reservoirs. The modified model versions were able to produce time series of daily groundwater levels, recharge to groundwater, groundwater abstraction and reservoir capacity. The performance of all the model variants was stronger in the Narmada basin. This was attributed to better quality input data, shallower groundwater and less aggressive groundwater abstraction. The volume of water released from all the major reservoirs studied was better represented, and the daily outflow from reservoirs with erratic releases significantly improved. Although these simplified routines improve the model performance throughout the basin, it is recommended that further application in a wider geographic area is necessary, to ensure the routines suitability represent a range of basin characteristics. Investigation into multiple parameter configurations would assist in quantifying uncertainty, and potentially improve abstractions and release parameters. 
Author Contributions: Conceptualization, R.H., H.E.B., A.K., T.T., K.K.G., and S.M.; methodology, R.H., A.K., N.J.R., H.E.B., V.D.J.K., and T.T.; software, S.M., H.E.B., A.K. and N.J.R.; validation, R.H., A.K.; formal analysis, R.H., N.J.R., A.K., and H.E.B.; investigation, R.H.; resources, T.T.; data curation, R.H., A.K., P.K.M., M.K.N., and R.P.; writing-original draft preparation, R.H.; writing-review and editing, N.J.R., H.E.B., T.T., V.D.J.K., and H.A.H.C.; visualization, R.H., and A.K.; supervision, V.D.J.K, H.A.H.C., and T.T; project administration, H.A.H.C, H.D., and V.D.J.K.; funding acquisition, H.D., S.K.J., and G.R. All authors have read and agreed to the published version of the manuscript.

Funding: The research underlying this paper was carried out under the UPSCAPE project of the Newton-Bhabha program "Sustaining Water Resources for Food, Energy and Ecosystem Services", funded by the UK Natural Environment Research Council (NERC-UKRI) and the India Ministry of Earth Sciences (MoES), grant number: NE/N016491/1 and Natural Environment Research Council award number NE/R000131/1 as part of the SUNRISE programme delivering National Capability. UK Centre for Ecology and Hydrology $(\mathrm{UKCEH})$ publish with the permission of the Director of UKCEH. The views and opinions expressed in this paper are those of the authors alone.

Data Availability Statement: Data utilized in this study can be found and download from the following sources:

Horan: R.; Keller, V.J.D.; Wable P.S.; Baron, H.E.; Houghton-Carr, H.A.; Rees, H.G. (2021). Simulated streamflow, demands and aquifer levels in the Cauvery Basin, India, 1986-2080 using the Global Water Availability Assessment Model (GWAVA). NERC Environmental Information Data Centre. https://doi.org/10.5285/522309f8-59b1-4982-85df-cb3171c2a062

Horan, R.; Rickards, N.; Kaelin, A.; Thomas, T.; Houghton-Carr, H.A. (2021). Simulated streamflow, demands and aquifer levels in the Narmada Basin, India, 1970-2099 using the Global Water Availability Assessment Model (GWAVA). NERC Environmental Information Data Centre. https://doi.org/10.5285/9fc7ab01-c622-46f1-a904-0bcd54073da3

Acknowledgments: In this section, you can acknowledge any support given which is not covered by the author contribution or funding sections. This may include administrative and technical support, or donations in kind (e.g., materials used for experiments).

Conflicts of Interest: Authors declare no conflicts of interest. 


\section{Appendix A}

Table A1 The spatial and temporal resolutions, periods and sources of the input data used in the set up of GWAVA in the Cauvery (C) and Narmada (N) basins

\begin{tabular}{|c|c|c|c|c|c|}
\hline Input data & Basin & $\begin{array}{c}\text { Spatial } \\
\text { Resolution }\end{array}$ & $\begin{array}{l}\text { Temporal } \\
\text { Resolution }\end{array}$ & Time Period & Source \\
\hline Precipitation & $\mathrm{C}, \mathrm{N}$ & 0.25 degree & Daily & 1951-2017 & Indian Meteorological Department [74] \\
\hline $\begin{array}{c}\text { Maximum } \\
\text { temperature }\end{array}$ & $\mathrm{C}, \mathrm{N}$ & 0.25 degree & Daily & $1951-2016$ & Indian Meteorological Department [74] \\
\hline $\begin{array}{c}\text { Minimum } \\
\text { temperature }\end{array}$ & $\mathrm{C}, \mathrm{N}$ & 0.25 degree & Daily & $1951-2016$ & Indian Meteorological Department [74] \\
\hline $\begin{array}{l}\text { Streamflow } \\
\text { gauged data }\end{array}$ & $\mathrm{C}, \mathrm{N}$ & Basin & Daily & $1971-2014$ & $\begin{array}{l}\text { Water Resources Information System of India (India-WRIS) } \\
\text { https://indiawris.gov.in/wris/\#/ }\end{array}$ \\
\hline $\begin{array}{c}\text { Reservoir } \\
\text { characteristics }\end{array}$ & $\begin{array}{l}\mathrm{C} \\
\mathrm{N}\end{array}$ & $\begin{array}{l}\text { Basin } \\
\text { Basin }\end{array}$ & & $\begin{array}{l}2018 \\
2020\end{array}$ & $\begin{array}{c}\text { India-WRIS } \\
\text { Narmada Control Authority, India- WRIS } \\
\end{array}$ \\
\hline $\begin{array}{l}\text { Reservoir inflow } \\
\text { and outflow data }\end{array}$ & $\begin{array}{l}\mathrm{C} \\
\mathrm{N}\end{array}$ & $\begin{array}{l}\text { Basin } \\
\text { Basin }\end{array}$ & $\begin{array}{l}\text { Monthly } \\
\text { Monthly }\end{array}$ & $\begin{array}{l}1974-2017 \\
2007-2017 \\
\end{array}$ & $\begin{array}{c}\text { India-WRIS } \\
\text { Narmada Control Authority } \\
\end{array}$ \\
\hline Reservoir storage & $\mathrm{C}, \mathrm{N}$ & Basin & Daily & $200-2010$ & India-WRIS \\
\hline Water transfers & $\begin{array}{l}\mathrm{C} \\
\mathrm{N}\end{array}$ & $\begin{array}{l}\text { Basin } \\
\text { Basin }\end{array}$ & $\begin{array}{l}\text { Annual } \\
\text { Annual }\end{array}$ & $\begin{array}{l}2008 \\
2009 \\
\end{array}$ & $\begin{array}{l}\text { Ashoka Trust for Research in Ecology and the Environment } \\
\text { Narmada Control Authority }\end{array}$ \\
\hline $\begin{array}{l}\text { Groundwater } \\
\text { levels }\end{array}$ & $\mathrm{C}, \mathrm{N}$ & District & Monthly & $1990-2017$ & Central Ground Water Board, India \\
\hline Elevation & $\mathrm{C}, \mathrm{N}$ & 0.003 degree & & 2000 & NASA Shuttle Radar Mission Global 1 arc second V003 [75] \\
\hline Geology & $\mathrm{C}, \mathrm{N}$ & Asia & & & United States Geological Survey \\
\hline Specific yield & $\mathrm{C}, \mathrm{N}$ & India & & & Central Ground Water Board, India \\
\hline Soil type & $\mathrm{C}$ & $\begin{array}{l}0.008 \text { degree } \\
1: 10000\end{array}$ & & $\begin{array}{c}1971-1981 \\
1958-2020\end{array}$ & $\begin{array}{c}\text { Harmonized World Soil Database v1.2 [76] } \\
\text { Soil and Land-use Survey of India } \\
\text { https://www.india.gov.in/website-soil-and-land-use-survey- } \\
\text { india }\end{array}$ \\
\hline Soil properties & $\mathrm{C}, \mathrm{N}$ & Global & & 2010 & Table 2- Allen et al. (2010) [77] \\
\hline $\begin{array}{l}\text { Land Cover } \\
\text { Land Use }\end{array}$ & $\mathrm{C}, \mathrm{N}$ & 0.001 degree & & 2005 & Decadal land use and land cover across India 2005 [78] \\
\hline Crops & $\begin{array}{l}\mathrm{C} \\
\mathrm{N}\end{array}$ & $\begin{array}{l}\text { Taluk }^{*} \\
5 \operatorname{arcmin}\end{array}$ & & $\begin{array}{l}2000 \\
2010 \\
\end{array}$ & $\begin{array}{l}\text { National Remote Sensing Centre (NRSC) } \\
\text { Portmann (2010) [79] }\end{array}$ \\
\hline
\end{tabular}




\begin{tabular}{|c|c|c|c|c|}
\hline $\begin{array}{l}\text { Total and Rural } \\
\text { Population }\end{array}$ & $\mathrm{C}, \mathrm{N}$ & Village & 2001 & $\begin{array}{l}\text { Census of India } 2001 \text { (http://sedac.ciesin.colum- } \\
\text { bia.edu/data/set/india-india-village-level-geospatial-socio- } \\
\text { econ-1991-2001) }\end{array}$ \\
\hline Livestock & C & 0.05 degree & 2005 & CGIR Livestock of the World v2 [80] \\
\hline $\begin{array}{c}\text { Conveyance } \\
\text { losses }\end{array}$ & $\mathrm{C}, \mathrm{N}$ & Village & 2011 & $\begin{array}{c}\text { Household \& Irrigation Census } 2011 \text { - Town and Village di- } \\
\text { rectory (https://censusindia.gov.in/DigitalLibrary/Tables- } \\
\text { eries2001.aspx }\end{array}$ \\
\hline $\begin{array}{l}\text { Irrigation } \\
\text { efficiency }\end{array}$ & $\mathrm{C}, \mathrm{N}$ & Continental & 1986 & Irrigation and Drainage Paper (FAO) No 1 \\
\hline $\begin{array}{l}\text { Surface- water } \\
\text { fraction }\end{array}$ & $\mathrm{C}$ & Village & 2011 & $\begin{array}{l}\text { Household \& Irrigation Census } 2011 \text { - Town and Village di- } \\
\text { rectory (https://censusindia.gov.in/DigitalLibrary/TablesS- } \\
\text { eries2001.aspx) }\end{array}$ \\
\hline $\begin{array}{c}\text { Livestock } \\
\text { demand }\end{array}$ & $\mathrm{C}, \mathrm{N}$ & India & 2006 & FAO (2018) [81] \\
\hline Domestic demand & $\mathrm{C}$ & Village & 2001 & $\begin{array}{c}\text { Household \& Irrigation Census } 2011 \text { - Town and Village di- } \\
\text { rectory (https://censusindia.gov.in/DigitalLibrary/Tables- } \\
\text { eries2001.aspx) } \\
\text { AQUASTAT [81] }\end{array}$ \\
\hline
\end{tabular}


Table B2 presents the demand constraints selected for each basin. These values were de- 4 rived from the Indian Decadal Census and the Indian Irrigation Census.

Table B2 Input Demand Constraints for the Cauvery and Narmada Basins

\begin{tabular}{ccc}
\hline Demand Constraints & Cauvery & Narmada \\
\hline Conveyance loss (\%)- Urban & 23 & 15 \\
Conveyance loss (\%)- Rural & 25 & 15 \\
Irrigation Efficiency (\%) & 44 & 70 \\
Return flow (\%)- Urban & 62 & 45 \\
Return flow (\%)- Rural & 0 & 45 \\
Demand per head (L/d)- Cattle & 77 & 40 \\
Demand per head (L/d)- Sheep and goat & 5 & 4 \\
Surface water abstraction (\%)- Urban & 44 & 57 \\
Surface water abstraction (\%)- Rural & 62 & 57 \\
Surface water abstraction (\%)- Industrial & 80 & 80 \\
Surface water abstraction (\%)- Irrigation & 31 & 47 \\
\hline
\end{tabular}




\section{Appendix B}

Table B1 The percent bias, monthly Nash-Sutcliffe Efficiency (NSE), monthly log-Nash Efficiency (LNE) and the monthly Kling-Gupta Efficiency (KGE) for each sub-catchment in the 10 Narmada and Cauvery basins. The metrics are provided for GWAVA (G), GWAVA-GW (G-GW), GWAVA-Res (G-Res) and GWAVA 5.1 (G 5.1).

\begin{tabular}{|c|c|c|c|c|c|c|c|c|c|c|c|c|c|c|c|c|}
\hline \multirow{2}{*}{$\begin{array}{c}\text { Sub- } \\
\text { catchment }\end{array}$} & \multicolumn{4}{|c|}{ Bias $(\%)$} & \multicolumn{4}{|c|}{ Monthly NSE } & \multicolumn{4}{|c|}{ Monthly LNE } & \multicolumn{4}{|c|}{ Monthly KGE } \\
\hline & G & G-GW & G-Res & G 5.1 & G & G-GW & G-Res & G 5.1 & G & G-GW & G-Res & G 5.1 & G & G-GW & G-Res & G 5.1 \\
\hline \multicolumn{17}{|c|}{ Narmada } \\
\hline Manot & 11.37 & 4.24 & 11.37 & 4.24 & 0.95 & 0.92 & 0.92 & 0.93 & 0.78 & 0.86 & 0.78 & 0.86 & 0.83 & 0.84 & 0.83 & 0.83 \\
\hline Mohgaon & 2.77 & 8.26 & 2.77 & 3.4 & 0.87 & 0.83 & 0.83 & 0.83 & 0.73 & 0.85 & 0.73 & 0.85 & 0.86 & 0.8 & 0.86 & 0.8 \\
\hline Patan & 17.17 & -0.77 & 17.17 & 12.3 & 0.9 & 0.83 & 0.83 & 0.91 & 0.59 & 0.83 & 0.59 & 0.91 & 0.77 & 0.75 & 0.77 & 0.83 \\
\hline Belkeri & 33.9 & 2.94 & 33.9 & 2.46 & 0.84 & 0.85 & 0.85 & 0.84 & 0.6 & 0.62 & 0.6 & 0.71 & 0.39 & 0.81 & 0.39 & 0.8 \\
\hline Gadarwara & 7.03 & -1.8 & 7.03 & 1 & 0.92 & 0.82 & 0.82 & 0.83 & -0.45 & 0.71 & -0.45 & 0.83 & 0.87 & 0.7 & 0.87 & 0.72 \\
\hline Chhidgaon & -12.36 & -45 & -12.36 & -13.29 & 0.89 & 0.62 & 0.62 & 0.86 & -0.33 & 0.66 & -0.33 & 0.88 & 0.85 & 0.6 & 0.85 & 0.77 \\
\hline Kogaon & 30.39 & -19.5 & 30.39 & 2.03 & 0.79 & 0.74 & 0.74 & 0.79 & -0.32 & 0.68 & -0.32 & 0.76 & 0.57 & 0.66 & 0.57 & 0.72 \\
\hline Barmanghat & 17.8 & 3.9 & -2.88 & 3.2 & 0.74 & 0.7 & 0.82 & 0.81 & 0.51 & 0.78 & 0.8 & 0.81 & 0.58 & 0.75 & 0.74 & 0.82 \\
\hline Sandia & 6.73 & 7.55 & 3.24 & 9.11 & 0.84 & 0.77 & 0.93 & 0.84 & 0.51 & -0.04 & 0.84 & 0.88 & 0.72 & 0.82 & 0.85 & 0.77 \\
\hline $\begin{array}{l}\text { Hoshanga- } \\
\text { bad }\end{array}$ & 7.57 & -0.68 & 2.92 & 0.4 & 0.89 & 0.82 & 0.94 & 0.9 & 0.08 & -0.94 & 0.85 & 0.90 & 0.83 & 0.84 & 0.84 & 0.78 \\
\hline Handia & 14 & 4.75 & 11.17 & 9.92 & 0.89 & 0.82 & 0.95 & 0.91 & -0.33 & -1.94 & 0.84 & 0.90 & 0.81 & 0.84 & 0.82 & 0.77 \\
\hline $\begin{array}{c}\text { Man- } \\
\text { dleshwar }\end{array}$ & 10.6 & 4.25 & 4.73 & 4.35 & 0.9 & 0.84 & 0.95 & 0.92 & 0.71 & -1.25 & 0.85 & 0.88 & 0.74 & 0.86 & 0.86 & 0.80 \\
\hline $\begin{array}{c}\text { Garudes- } \\
\text { hwar }\end{array}$ & 16.09 & 12.74 & 4.43 & 13.4 & 0.9 & 0.78 & 0.94 & 0.9 & 0.18 & -1.8 & 0.84 & 0.89 & 0.74 & 0.83 & 0.85 & 0.80 \\
\hline \multicolumn{17}{|c|}{ Cauvery } \\
\hline Saklesphur & -37 & -46.4 & -37 & -46.4 & 0.77 & 0.57 & 0.77 & 0.57 & 0.31 & 0.81 & 0.31 & 0.81 & 0.59 & 0.53 & 0.59 & 0.53 \\
\hline $\begin{array}{c}\text { Thim- } \\
\text { manahali }\end{array}$ & $\begin{array}{l}-58.1 \\
\end{array}$ & -3.6 & $\begin{array}{l}-58.1 \\
\end{array}$ & -3.6 & 0.21 & 0.71 & 0.21 & 0.71 & 0.34 & 0.58 & 0.34 & 0.58 & 0.36 & 0.84 & 0.36 & 0.84 \\
\hline KMVadi & -21 & $\begin{array}{l}-50.3 \\
\end{array}$ & -21 & $\begin{array}{l}-50.3 \\
\end{array}$ & 0.21 & 0.14 & 0.21 & 0.14 & 0.14 & -0.07 & 0.14 & -0.07 & 0.29 & 0.25 & 0.29 & 0.25 \\
\hline Kudige & -43 & -50.7 & -43 & -50.7 & 0.67 & 0.55 & 0.67 & 0.55 & 0.70 & 0.70 & 0.70 & 0.70 & 0.53 & 0.48 & 0.53 & 0.48 \\
\hline $\begin{array}{l}\text { Munthank- } \\
\text { era }\end{array}$ & -21.6 & -25.4 & -21.6 & $\begin{array}{l}-25.4 \\
\end{array}$ & 0.8 & 0.78 & 0.8 & 0.78 & 0.74 & 0.89 & 0.74 & 0.89 & 0.73 & 0.73 & 0.73 & 0.73 \\
\hline $\begin{array}{l}\text { Thenguma- } \\
\text { rahada }\end{array}$ & 1.2 & -22.3 & 1.2 & -22.3 & 0.07 & 0.43 & 0.07 & 0.43 & 0.22 & 0.59 & 0.22 & 0.59 & 0.50 & 0.57 & 0.50 & 0.57 \\
\hline T narasupiar & -13.4 & -12.0 & 3.6 & -11.6 & 0.66 & 0.6 & 0.75 & 0.6 & -9.83 & -1.6 & -0.4 & -1.2 & 0.77 & 0.75 & 0.83 & 0.75 \\
\hline Kollegal & -33.6 & -16.9 & -15.4 & -24.9 & 0.54 & 0.56 & 0.70 & 0.56 & -7.46 & -2.18 & 0.69 & 0.56 & 0.58 & 0.7 & 0.68 & 0.65 \\
\hline
\end{tabular}




\begin{tabular}{|c|c|c|c|c|c|c|c|c|c|c|c|c|c|c|c|c|}
\hline Tbekuppe & 2.6 & -5.4 & -12 & -5.4 & -0.81 & -0.09 & 0.62 & 0.49 & -23.97 & -0.72 & 0.53 & -0.72 & 0.21 & 0.41 & 0.38 & 0.41 \\
\hline TKHali & 4.1 & 7.3 & 3.4 & 7.3 & 0.36 & 0.43 & 0.4 & 0.43 & -1.68 & -0.29 & -0.91 & -0.29 & 0.57 & 0.52 & 0.61 & 0.52 \\
\hline Bilingudulu & -14.7 & -2.2 & 12.1 & -10.5 & 0.63 & 0.5 & 0.79 & 0.64 & 0.07 & -0.77 & 0.69 & 0.65 & 0.76 & 0.74 & 0.73 & 0.77 \\
\hline Urachikottai & -4.6 & -11.5 & 21.0 & 9.3 & 0.09 & -0.35 & 0.13 & 0.57 & 0.07 & -0.77 & 0.69 & 0.71 & 0.56 & 0.34 & 0.56 & 0.66 \\
\hline Kodumodi & -14.5 & -22.7 & 20.0 & -5.9 & 0.14 & -0.3 & 0.52 & 0.64 & -1.56 & -3.80 & 0.41 & 0.51 & 0.52 & 0.25 & 0.56 & 0.76 \\
\hline Musiri & -5.8 & -6.8 & 18.2 & -2.1 & 0.15 & -0.45 & 0.14 & 0.66 & -0.81 & -1.69 & -0.12 & 0.37 & 0.58 & 0.33 & 0.28 & 0.79 \\
\hline
\end{tabular}




\section{References}

1 Döll P, Douville H, Güntner A, Schmied HM, Wada Y. Modelling freshwater resources at the global scale: challenges and prospects. Surveys in Geophysics. 2016; 37(2):195-221.

2 Vorosmarty CJ, Hoekstra AY, Bunn SE, Conway D, Gupta J. Fresh water goes global. Science. 2015; 349(6247):478-9.

3 Liu Y, Gupta H, Springer E, Wagener T. Linking science with environmental decision making: Experiences from an integrated modeling approach to supporting sustainable water resources management. Environmental Modelling \& Software. 2008; 23(7):846-58.

4 Kingston D, Massei N, Dieppois B, Hannah D, Hartmann A, Lavers D, Vidal JP. Moving beyond the catchment scale: Value and opportunities in large-scale hydrology to understand our changing world. Hydrological Processes. 2020; 34(10):2292-8.

5 Meigh JR, McKenzie AA, Sene KJ. A grid-based approach to water scarcity estimates for eastern and southern Africa. Water Resources Management. 1999; 13(2):85-115.

6 Famiglietti JS. The global groundwater crisis. Nature Climate Change. 2014; 4(11):945-8.

7 MacKellar NC, Dadson SJ, New M, Wolski P. Evaluation of the JULES land surface model in simulating catchment hydrology in Southern Africa. Hydrology and Earth System Sciences Discussions. 2013; 10(8):11093-128.

8 Clark MP, Fan Y, Lawrence DM, Adam JC, Bolster D, Gochis DJ, Hooper RP, Kumar M, Leung LR, Mackay DS, Maxwell RM. Improving the representation of hydrologic processes in Earth System Models. Water Resources Research. 2015; 51(8):5929-56.

9 Pokhrel YN, Hanasaki N, Wada Y, Kim H. Recent progresses in incorporating human land-water management into global land surface models toward their integration into Earth system models. Wiley Interdisciplinary Reviews: Water. 2016; 3(4):548-74.

10 Scheidegger JM, Jackson CR, Muddu S, Tomer SK, Filgueira R. Integration of 2D lateral groundwater flow into the variable infiltration capacity (VIC) model and effects on simulated fluxes for different grid resolutions and aquifer diffusivities. Water. 2021; 13(5):663.

11 Hanasaki N, Yoshikawa S, Pokhrel Y, Kanae S. A global hydrological simulation to specify the sources of water used by humans. Hydrology and Earth System Sciences. 2018; 22(1):789-817.

12 Sutanudjaja EH, Van Beek R, Wanders N, Wada Y, Bosmans JH, Drost N, Van Der Ent RJ, De Graaf IE, Hoch JM, De Jong K, Karssenberg D. PCR-GLOBWB 2: a 5 arcmin global hydrological and water resources model. Geoscientific Model Development. 2018; 11(6):2429-53.

13 Burek P, Satoh Y, Kahil T, Tang T, Greve P, Smilovic M, Guillaumot L, Zhao F, Wada Y. Development of the Community Water Model (CWatM v1. 04)-a high-resolution hydrological model for global and regional assessment of integrated water resources management. Geoscientific Model Development. 2020; 13(7):3267-98.

14 Müller Schmied H, Cáceres D, Eisner S, Flörke M, Herbert C, Niemann C, Peiris TA, Popat E, Portmann FT, Reinecke R, Schumacher M. The global water resources and use model WaterGAP v2. 2d: model description and evaluation. Geoscientific Model Development. 2021; 14(2):1037-79.

15 Droppers B, Franssen WH, Van Vliet MT, Nijssen B, Ludwig F. Simulating human impacts on global water resources using VIC-5. Geoscientific Model Development. 2020; 13(10):5029-52.

16 Harbaugh AW. MODFLOW-2005, the US Geological Survey modular ground-water model: the ground-water flow process. Reston, VA: US Department of the Interior, US Geological Survey; 2005.

17 Downing JA, Prairie YT, Cole JJ, Duarte CM, Tranvik LJ, Striegl RG, McDowell WH, Kortelainen P, Caraco NF, Melack JM, Middelburg JJ. The global abundance and size distribution of lakes, ponds, and impoundments. Limnology and Oceanography. 2006; 51(5):2388-97.

18 Zhao G, Gao H, Naz BS, Kao SC, Voisin N. Integrating a reservoir regulation scheme into a spatially distributed hydrological model. Advances in Water Resources. 2016; 98:16-31.

19 Haddeland I, Skaugen T, Lettenmaier DP. Anthropogenic impacts on continental surface water fluxes. Geophysical Research Letters. 2006; 33(8).

20 Döll P, Kaspar F, Lehner B. A global hydrological model for deriving water availability indicators: model tuning and validation. Journal of Hydrology. 2003; 270(1-2):105-34.

21 Hanasaki N, Kanae S, Oki T. A reservoir operation scheme for global river routing models. Journal of Hydrology. 2006; 327(12):22-41.

22 Hanasaki N, Kanae S, Oki T, Masuda K, Motoya K, Shirakawa N, Shen Y, Tanaka K. An integrated model for the assessment of global water resources-Part 1: Model description and input meteorological forcing. Hydrology and Earth System Sciences. 2008; 12(4):1007-25.

23 Biemans H, Haddeland I, Kabat P, Ludwig F, Hutjes RW, Heinke J, von Bloh W, Gerten D. Impact of reservoirs on river discharge and irrigation water supply during the 20th century. Water Resources Research. 2011; 47(3).

24 Chen J, Wu Y. Advancing representation of hydrologic processes in the Soil and Water Assessment Tool (SWAT) through integration of the TOPographic MODEL (TOPMODEL) features. Journal of hydrology. 2012; 420:319-28.

25 Yassin F, Razavi S, Elshamy M, Davison B, Sapriza-Azuri G, Wheater H. Representation and improved parameterization of reservoir operation in hydrological and land-surface models. Hydrology and Earth System Sciences. 2019; 23(9):3735-64.

26 Tefs AA, Stadnyk TA, Koenig KA, Dery SJ, Macdonald MK, Slota P, Crawford J, Hamilton M. Simulating river regulation and reservoir performance in a continental-scale hydrologic model. Environmental Modelling \& Software. 2021; 141:105025.

27 Madhusoodhanan CG, Sreeja KG, Eldho TI. Climate change impact assessments on the water resources of India under extensive human interventions. Ambio. 2016; 45(6):725-41. 

the hydrology of the Upper Narmada. Water. 2020; 12(6):1762.

53 Tomer SK, Al Bitar A, Sekhar M, Merlin O, Bandyopadhyay S, Kerr YH. An Intercomparison of RADARSAT-2, SMOS and Field Measured Soil Moisture in the Berambadi Watershed, South India. In AGU Fall Meeting Abstracts 2012 Dec (Vol. 2012, pp. H13F-1425).

54 McDonald MG, Harbaugh AW. A modular three-dimensional finite-difference ground-water flow model. US Geological Survey; 1988.

55 Subash Y, Sekhar M, Tomer S and Sharma A, A framework for assessment of climate change impacts on the groundwater system, in Sustainable Water Resources Management, ASCE Book Chapter, 2016.

56 Mondal A, Narasimhan B, Sekhar M, Mujumdar PP. Hydrologic modelling. Proceedings of the Indian National Science Academy-Part A: Physical Sciences. 2016; 82(3):817-832. 
57 Sekhar M, Riotte J, Ruiz L, Jouquet P, Braun JJ. Influences of climate and agriculture on water and biogeochemical cycles: Kabini Critical Zone Observatory. Proceedings of the Indian National Science Academy. 2016; 82(3):833-846.

58 Robert M, Thomas A, Sekhar M, Raynal H, Casellas É, Casel P, Chabrier P, Joannon A, Bergez JÉ. A dynamic model for water management at the farm level integrating strategic, tactical and operational decisions. Environmental modelling \& software. 2018; 100:123-135.

59 de Bruin A, de Condappa D, Mikhail M, Tomer SK, Sekhar M, Barron J. Simulated water resource impacts and livelihood implications of stakeholder-developed scenarios in the Jaldhaka Basin, India. Water international. 2012; 37(4):492-508.

60 Baron H, Keller V, Simpson M, Collins S, Jackson C and Muddu D, Extending the GWAVA model to better represent water resources in the Cauvery basin, in Sustainable Water Futures, Bangalore, 2019.

61 Hanasaki N, Kanae S, Oki T. A reservoir operation scheme for global river routing models. Journal of Hydrology. 2006; 327(12):22-41.

62 Hanasaki N, Inuzuka T, Kanae S, Oki T. An estimation of global virtual water flow and sources of water withdrawal for major crops and livestock products using a global hydrological model. Journal of Hydrology. 2010; 384(3-4):232-244.

$63 \mathrm{Wu}$ Y, Chen J. An operation-based scheme for a multiyear and multipurpose reservoir to enhance macroscale hydrologic models. Journal of Hydrometeorology. 2012; 13(1):270-283.

64 Zhao G, Gao H, Naz BS, Kao SC, Voisin N. Integrating a reservoir regulation scheme into a spatially distributed hydrological model. Advances in Water Resources. 2016; 98(1):16-31.

65 Wang K, Shi H, Chen J, Li T. An improved operation-based reservoir scheme integrated with Variable Infiltration Capacity model for multiyear and multipurpose reservoirs. Journal of Hydrology. 2019; 571(1):365-375.

66 Thomas T, Ghosh NC, Sudheer KP. Optimal reservoir operation-A climate change adaptation strategy for Narmada basin in central India. Journal of Hydrology. 2021; 598(1):126238.

67 Goswami SB, Kar SC. Simulation of water cycle components in the Narmada River basin by forcing SWAT model with CFSR data. Meteorology Hydrology and Water Management. Research and Operational Applications. 2018; 6(1):13--25.

68 Pechlivanidis IG, Arheimer B. Large-scale hydrological modelling by using modified PUB recommendations: the India-HYPE case. Hydrology and Earth System Sciences. 2015; 19(11):4559-4579.

69 Nema S, Awasthi MK, Nema RK. Conceptual groundwater modelling in an alluvial aquifer of upper Narmada basin. Journal of Soil and Water Conservation. 2019; 18(2):179-187.

70 Maheswaran R, Khosa R. Wavelet-Volterra coupled model for monthly stream flow forecasting. Journal of Hydrology. 2012; 450(1):320-335.

71 Collins SL, Loveless SE, Muddu S, Buvaneshwari S, Palamakumbura RN, Krabbendam M, Lapworth DJ, Jackson CR, Gooddy DC, Nara SN, Chattopadhyay S. Groundwater connectivity of a sheared gneiss aquifer in the Cauvery River basin, India. Hydrogeology Journal. 2020; 28(4):1371-1388.

72 Hora T, Srinivasan V, Basu NB. The groundwater recovery paradox in South India. Geophysical Research Letters. 2019; 46(16):9602-9611.

73 Beven, K. A manifesto for the equifinality thesis. J. Hydrol. 2006, 320(1): 18-36.

74 Pai DS, Rajeevan M, Sreejith OP, Mukhopadhyay B, Satbha NS. Development of a new high spatial resolution (0.25× 0.25$)$ long period (1901-2010) daily gridded rainfall data set over India and its comparison with existing data sets over the region. Mausam. 2014; 65(1):1-8.

75 NASA Jet Propulsion Laboratory (JPL), NASA Shuttle Radar Topography Mission Global 1 arc Second Number, National Aeronautics and Space Administration, U.S. Government, NASA. EOSDIS Land Processes DAAC, NASA JPL: Pasadena, CA, USA, 2013.

76 Fischer G, Nachtergaele F, Prieler S, van Velthuizen H, Verelst L and Wiberg D, Global Agro-Ecological Zones Assessment for Agriculture, Laxenburg, Austria, 2008, p. 26-31.

77 Allen DM, Cannon AJ, Toews MW, Scibek J. Variability in simulated recharge using different GCMs. Water Resources Research. $2010 ; 46(10)$.

78 Roy PS, Meiyappan P, Joshi PK, Kale MP, Srivastav VK, Srivasatava SK, Behera MD, Roy A, Sharma Y, Ramachandran RM, Bhavani P. Decadal Land Use and Land Cover Classifications across India, 1985, 1995, 2005. ORNL DAAC. 2016.

79 Portmann FT, Siebert S, Döll P. MIRCA2000-Global monthly irrigated and rainfed crop areas around the year 2000: A new high-resolution data set for agricultural and hydrological modeling. Global biogeochemical cycles. 2010; 24(1).

80 Robinson TP, Wint GW, Conchedda G, Van Boeckel TP, Ercoli V, Palamara E, Cinardi G, D'Aietti L, Hay SI, Gilbert M. Mapping the global distribution of livestock. PloS one. 2014; 9(5):e96084.

81 Food and Agriculture Organization of the United Nations, AQUASTAT, Food and Agriculture Organization of the United Nations, Online. Available: http://www.fao.org/aquastat/statistics/query/index.html?lang=en. 